\title{
INTERVENÇÕES ARQUITETÔNICAS NO CENTRO HISTÓRICO DE BELÉM: A PRÁTICA PROJETUAL CONTEMPORÂNEA
}

\section{ARCHITECTURAL INTERVENTIONS IN THE HISTORIC CENTER OF BELEM: THE CONTEMPORARY PROJECTUAL PRATICE}

\author{
Márcia Teixeira Filgueira Forte 1 \\ Universidade Federal do Pará, Belém, PA, Brasil, marciatfforte@ gmail.com \\ Thais Alessandra Bastos Caminha Sanjad ${ }^{2}$ \\ Universidade Federal do Pará, Belém, PA, Brasil, thaisabcs2@ gmail.com
}

\begin{abstract}
Resumo
A discussão acerca da produção arquitetônica contemporânea como intervenção no patrimônio construído é tema que precisa ser mais abordado nas universidades brasileiras, e alvo de muita polêmica entre os profissionais. Considerando que a demanda de nossos centros urbanos impõe cotidianamente o desafio de projetar em espaços de memória, este artigo tem como objetivo discutir a prática projetual contemporânea dentro desse contexto, e estabelece como universo o Centro Histórico de Belém. A escolha dos objetos de análise se fundamentou em alguns aspectos primordiais a uma discussão mais ampla, por envolver três edificações tombadas, com projetos desenvolvidos após a legislação de proteção e que representam propostas transformadoras no cenário local. Estas edificações foram: o Ver-o-Peso, representante da identidade cultural da capital; o Sesc Boulevard, que faz parte do skyline frontal da cidade; e o edifício Bechara Mattar, que rompe de forma ostensiva com a tipologia do núcleo primitivo do Centro Histórico. Merece destaque nessa reflexão a observação dos parâmetros que vieram a subsidiar a tomada de decisões dos arquitetos, dos elementos de referência utilizados, das dificuldades encontradas, e da influência das discussões teórico-acadêmicas no processo projetual. Busca-se ampliar o debate acerca da "liberdade" projetual em áreas históricas e estimular um olhar profissional mais sensível, em prol de atitudes contemporâneas conscientes do valor das preexistências.
\end{abstract}

Palavras-chave: Patrimônio arquitetônico. Construir no construído. Centro Histórico de Belém. Intervenção. Prática projetual.

\begin{abstract}
The discussion about the contemporary architectural production as intervention in the built patrimony is a subject that needs to be further explored in Brazilian universities, and is the target of much controversy between professionals. Considering the demand of our urban centers, that daily imposes the challenge of design in memory spaces, this article aims to discuss the contemporary projectual practice in this context, and establishes as universe of discourse the Historical Center of Belem. The choice of objects of analysis is based on aspects that promote a broader discussion, by involving three tumbled buildings, with intervention projects developed after the establishment of protection laws and representing transforming proposals on the local scene. These buildings were: the Ver-o-Peso, a representative of the cultural identity of Belem; the Sesc Boulevard, building which is part of the front skyline of the city; Bechara Mattar building, that breaks ostensibly with the tipology of primitive nucleus of Historical Center. It's noteworthy in this reflection the observation of projectual parameters of architects, of reference elements used, of the difficulties encountered, of the influence of theoretical and academic discussions for the projectual process. It is intended to extend the discussion on the "freedom" of designing in historic areas and stimulate a sensitive professional view, in favor of contemporary attitudes conscious of the preexistences value.
\end{abstract}

Keywords: Architectural heritage. Build in the built. Historical Center of Belem. Intervention. Projectual pratice.

\section{How to cite this article:}

FORTE, Márcia Teixeira Filgueira; SANJAD, Thais Bastos Caminha. Intervenções arquitetônicas no centro histórico de Belém: a prática projetual contemporânea. PARC Pesquisa em Arquitetura e Construção, Campinas, SP, v. 6, n. 3, p. 188-204, set. 2015. ISSN 1980-6809. Disponível em: <http://periodicos.sbu.unicamp.br/ojs/index.php/parc/article/view/8640703>. Acesso em: 11 mar. 2016. doi:http://dx.doi.org/10.20396/parc.v6i3.8640703. 


\section{Introdução}

O Centro Histórico de Belém (CHB), tombado em 1994 pelo poder público municipal e em 2012 em esfera federal, é composto por cerca de três mil edificações, abrangendo os bairros da Campina e Cidade Velha, área que representa o núcleo inicial da cidade de Belém. O local se apresenta bastante descaracterizado, em função de uma legislação de proteção tardia, com inúmeras alterações em razão do progresso indisciplinado, fruto de um longo período com insuficientes políticas públicas e mecanismos de proteção incapazes de salvaguardar o conjunto histórico da cidade.

A partir da legislação municipal de proteção (Lei de Preservação e Proteção do Patrimônio Histórico, Artístico, Ambiental e Cultural do Município de Belém $\mathrm{n}^{\circ}$ 7.709, de 1994) os imóveis do CHB foram classificados de acordo com o nível de preservação e o grau de intervenção a que estariam submetidos. Essa classificação inclui cinco categorias: preservação arquitetônica integral, preservação arquitetônica parcial, imóveis de reconstituição arquitetônica, de acompanhamento e de renovação.

Desde então, o nível de liberdade projetual dentro desta área passou a acompanhar uma escala de intervenção, com ações que variam: desde a total restrição de atuação num determinado imóvel (considerado de preservação integral), a uma maior liberdade na escala denominada de renovação; na qual o objeto é considerado "sem interesse a preservação" (Lei Municipal no 7.709/94).

As transformações sofridas ao longo dos anos, em especial a partir da década de 1960 quando um surto de verticalização destruiu parte do patrimônio edificado do $\mathrm{CHB}$, deixaram marcas profundas nessa área, a partir da alteração morfológica de alguns conjuntos e das agressivas intervenções em função da atividade comercial, que assumiu proporção significativa, devastando parte da identidade dessa importante região.

Ao abordar a temática projetual contemporânea dentro do CHB, foram selecionados três objetos de análise: 1) o Complexo Ver-o-Peso, importante cartão postal da cidade e principal representante da identidade cultural da população de Belém; 2) o Sesc Boulevard, que faz parte do skyline frontal da cidade; 3) o edifício Bechara Mattar, inserido numa área cercada pelos primeiros tombamentos da capital, que rompe de forma ostensiva com a tipologia do local, observado sob o ponto de vista de apresentar uma possibilidade de amenizar o dano ao conjunto. Esses objetos de análise foram elencados a partir de seus graus de intervenção, com base na abordagem conceitual de Gracia $(1991)^{1}$, inseridos no polígono de tombamento, todos com projetos executados pós-legislação de proteção de 1994, e que representam propostas transformadoras no cenário da capital paraense.

O Ver-o-Peso representa o nível apresentado por Gracia (1991) como pauta de conformação urbana ${ }^{2}$, simbolizando uma intervenção com alcance urbano, que afeta de forma direta a morfologia da área a partir do momento em que faz parte de um complexo cultural de forte identidade. Durante os seus quase quatro séculos de existência, passou por várias transformações, dentre as quais foram observadas as intervenções mais notáveis, em especial o projeto que atualmente faz parte da paisagem desse expressivo local para a cidade.

O Sesc Boulevard reproduz o que Gracia (1991) categoriza como modificação circunscrita ${ }^{3}$, a partir do momento em que se restringe ao edifício de modo isolado, que sofre uma ampliação moderada e transformações na estrutura interna, com restaurações em sua fachada que repercutem de forma sutil sobre o casario do entorno.

O edifício Bechara Mattar ainda se encontra com o projeto em processo de análise, corresponde ao nível denominado modificação do lócus ${ }^{4}$ por Gracia (1991). Representa uma intervenção em edificação da década de 1970, agressiva ao entorno. O projeto, apesar de restrito ao edifício de forma pontual, termina por repercutir sobre a paisagem construída; tendo em vista que a imagem urbana tem a escala modificada.

O objetivo deste artigo é discutir a prática projetual contemporânea no Centro Histórico de Belém, de modo a identificar, dentre os objetos selecionados, importantes contribuições que demonstrem como: intervir na preexistência de maneira atual e harmônica, sem romper com a unidade dos conjuntos edificados, e preservar a identidade de nossos centros urbanos.

\section{Projetar no Centro Histórico: "Uma liberdade vigiada"}

O pensamento projetual referente à ação na preexistência, inserida em área histórica, requer, além da afirmação de seu valor como arquitetura, uma leitura mais sensível da expressão da intervenção quando confrontada com os remanescentes históricos que compõem o seu conjunto. Dentro das discussões contemporâneas, autores associam ainda, além de sua representatividade arquitetônica, duas outras características, a documental e a simbólica.

A liberdade de ação nessas edificações, por estar condicionada a estes fatores, pode ser considerada uma "liberdade vigiada", que tem como limites o próprio edifício e sua representatividade no contexto urbano, a legislação de proteção que regulamenta as ações na área, 
o entorno imediato que compõe seu conjunto e o seu valor simbólico.

Ao se deparar com o desafio de projetar na preexistência, $\mathrm{o}$ arquiteto, muitas vezes munido de um desconhecimento ou dificuldade de interpretação da teoria e da legislação existente, assume posições adversas e tende, por um lado, a optar pelo simplismo que beira a arquitetura de pastiche, ou, no outro extremo, ignorar o contexto, aproximando-se de um exagero descaracterizador. Discussões acerca do processo projetual de intervenção em um edifício preexistente se fazem necessárias, de modo a estimular a reflexão dos profissionais e colaborar com atitudes criativo-conscientes, que fujam dos dois extremos citados, a favor de resultados positivos às cidades.

As teorias do século XIX fazem parte de uma trajetória de pensamento centrada na materialidade do objeto. Dentre os teóricos que mais se aproxima da atualidade, Riegl (2013) assume importante papel ao trazer um conceito mais completo de monumento, discutindo os valores dos mesmos, e atribui pela primeira vez valores de atualidade, como o valor de uso e o de novidade. Brandi (2008), chama a atenção para o restauro crítico, o "juízo de valor", na busca pela unidade potencial da obra de arte em prol de um resultado que resgate a integridade do conjunto sem prejuízos a sua autenticidade.

As reflexões contemporâneas, em contato com as transformações sofridas no contexto urbano, dão destaque aos significados do patrimônio cultural e a funcionalidade como fundamental à sua conservação. Essa mudança de posicionamento já se mostrava bastante evidente, desde que Giovannoni (1929) afirmou a importância do entorno construído, ampliando o campo de observação para o universo da cidade.

Dourado (1989) reconhece que, a partir do Iluminismo, a postura de conservação da memória e transmissão da tradição é rompida, substituída pela razão e pela ciência, tomada como paradigma do saber, e, juntamente à Revolução Francesa, deixa como legado a renegação ao passado, a ordem racional da cultura e a ideia de progresso ilimitado, elementos impulsionadores da concepção do projeto moderno.

Segundo Gracia (1991) no século XX os movimentos artísticos e arquitetônicos se mostraram contrários à sua própria continuidade, demonstrando posturas antihistoricistas, que deixam como uma das maiores sequelas a atitude arrogante de modificação dos lugares por parte dos arquitetos. Gracia (1991) defende uma postura de conciliação entre o passado e os procedimentos modernos, e deixa clara a sua preferência por uma arquitetura em que a forma deriva da compreensão formal da história.
Rossi (1995) e Argan (1998) apresentam posicionamento que se mostra contrário à cidade histórica intacta, reconhecendo a coexistência do novo com o velho, a dinamização da cidade, que representa a cultura em transformação. Para Rossi (1995) o que enobrece a cidade é sua constante metamorfose, na qual diferentes tempos coabitam em um mesmo núcleo urbano. Rossi (1995) adota ainda a continuidade da paisagem como critério para a intervenção arquitetônica, e destaca a leitura dos elementos mais significativos, que, quando preservados, contribuem com a possibilidade de contemplação da paisagem preexistente em harmonia com a nova arquitetura.

Dentre os teóricos contemporâneos, também conhecidos como pós-brandianos, Moreno-Navarro (1999) cita uma profunda crise, no final do século passado, dos princípios consolidados sobre o conceito e alcance do patrimônio, enfatizando a obsolescência da maior parte das teorias que pretendiam pautar as intervenções.

Nenhuma teoria universal formulada ao longo destes dois séculos tem gerado, por si só, respostas globais válidas para afrontar a complexa problemática de cada ação em particular. Uma incapacidade que tem piorado nas últimas décadas (MORENO-NAVARRO, 1999, p. 11. Tradução da autora).

Moreno-Navarro (1999) defende ainda a recuperação do espaço como imprescindível para garantir a autenticidade dos monumentos. O autor associa a denominação de patrimônio arquitetônico aos edifícios que estão relacionados a sentimentos de admiração, nostalgia ou esperança de uma comunidade, além de considerá-los testemunhos de destaque ou símbolos de atividades e relações sociais, valorizando a criatividade $\mathrm{e}$ engenhosidade de seus autores e construtores.

Muñoz-Viñas (2004) se opõe audaciosamente à teoria brandiana, quando argumenta que nem todo objeto de restauração é obra de arte, vinculando aos mesmos, outros valores que vão além do histórico e artístico, como os ideológicos, sentimentais ou religiosos, e avança quando chama atenção para o diálogo, a interdisciplinaridade e sustentabilidade como caminhos fundamentais a resultados positivos. Critica a supervalorização da instância estética e a ausência de discussões a respeito da utilidade/funcionalidade do objeto.

Apesar dos avanços percebidos nas discussões teóricas, ainda são observadas inconsistências entre teoria e prática conflituosas. Muitos profissionais, ao se depararem com um edifício preexistente, anulam sua capacidade criativa por entenderem que, fazendo parecer antiga uma intervenção atual, estão contribuindo para sua preservação no conjunto urbano. A arquitetura de pastiche, por simular uma "falsa antiguidade", 
desqualifica o conjunto e representa uma fraude quando assume a finalidade de forjar a história.

Um famoso exemplo de pastiche, considerado por alguns arquitetos, sobretudo os adeptos à teoria brandiana, é a restauração do antigo Casarão do Hotel Pilão na Praça de Tiradentes, em Ouro Preto, que sofreu um incêndio em 2003, tendo sido reconstruído em 2006 (Figura 1). Ao discorrer a respeito da intervenção, antes de sua execução, Dourado (2003) traz uma importante contribuição à discussão quando reconhece a cidade como obra de arte e, portanto, portadora de uma unidade formal do conjunto, atentando para os riscos da "falsa antiguidade", embasada em princípios brandianos, quando cita:

\section{[...] o velho casarão está irremediavelmente perdido, nada poderá trazê-lo de volta. Reconstruí-lo na sua aparência de casarão do século XVIII, mesmo com a utilização de materiais contemporâneos e simplificação formal - na tentativa velada de evitar um falso histórico - não camuflaria um atentado contra a arte: a sua expressão formal dificilmente fugiria do epíteto de pastiche, desqualificando a arquitetura contemporânea e fazendo empalidecer a antiga (DOURADO, 2003, p. 13).}

Figura 1 - A) Vista do casarão um dia após o incêndio em 2003. B) Vista do casarão após reconstrução
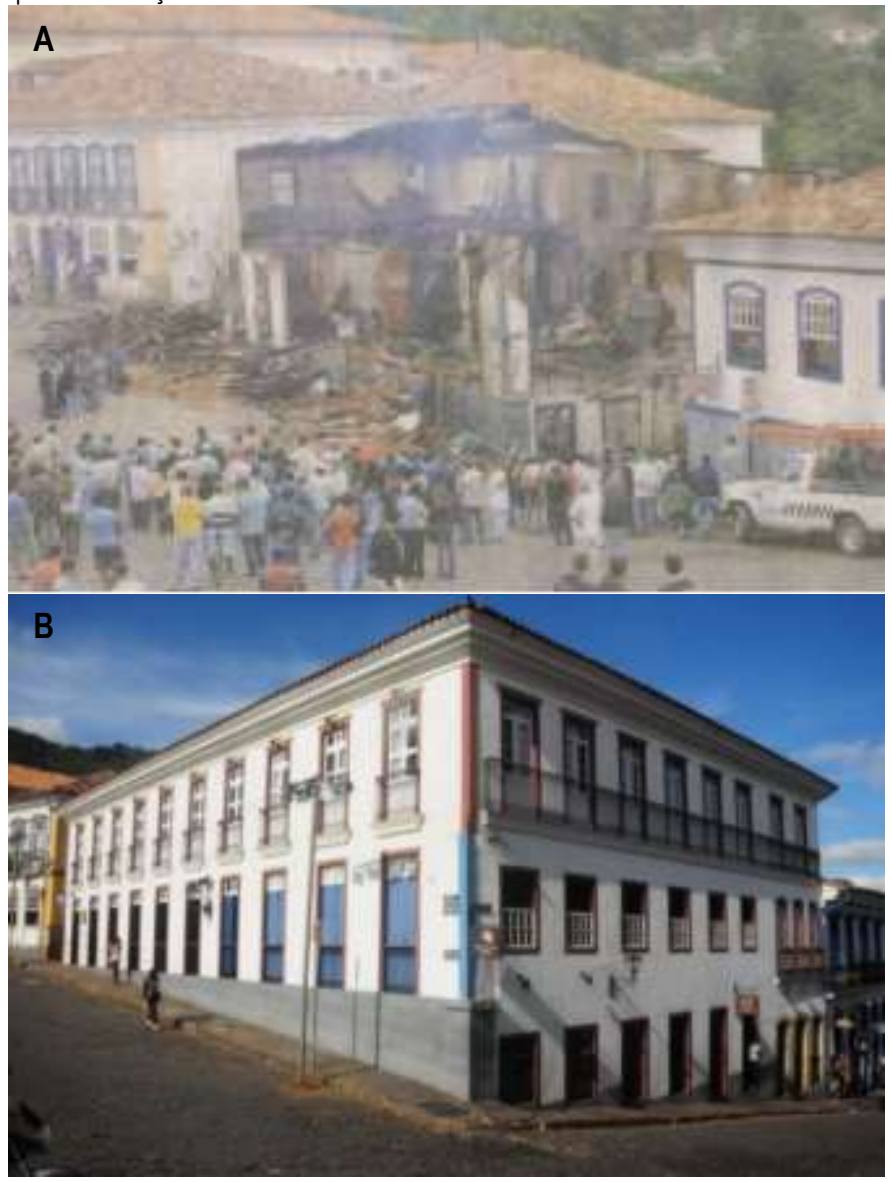

Fonte: A) Foto: Marcelo Sant'Anna, jornal Estado de Minas, Belo Horizonte, p. 01 (capa), 16 de abril de 2003. B) http://www.cafeculturalop.com.br. Acesso em 17 de jun.2015
Porém, as abordagens contemporâneas, ao ampliarem a leitura dos elementos de referência de uma edificação histórica, incluem uma preocupação maior com o valor simbólico da obra e com sua representatividade à população de um determinado local, contemplando essas referências como aspecto positivo na construção de uma identidade, como sugerido na Carta de Cracóvia, de 26 de outubro de $2000^{5}$.

Ao considerar o conjunto da Praça de Tiradentes dotado de forte simbolismo para a população local, surgia então o difícil questionamento: como proceder a partir da lacuna deixada pelo incêndio? $\mathrm{O}$ poder público optou pelo resgate da imagem que compunha a paisagem do conjunto. A alternativa da reconstrução considerou alguns fatores determinantes, pautados no sentimento de que seria desejo da maioria da população a reconstrução do antigo edifício e na complexidade de uma intervenção em um conjunto arquitetônico tão harmônico e significativo para a cidade (GRAMMONT, 2006).

A partir de então o casarão foi reconstruído com materiais novos, como a estrutura metálica da cobertura, novas paredes foram erguidas, deixando registro das partes remanescentes, de modo a distinguir claramente os materiais e técnicas originais e contemporâneos, e a edificação foi completamente reedificada internamente, de modo a atender ao novo uso: Centro Cultural e Turístico do Sistema FIEMG - Federação das Indústrias do Estado de Minas Gerais.

O extremo oposto a essa atitude pode representar a descontinuidade arquitetônica de conjuntos históricos, partindo do pressuposto da oposição ostensiva do edifício novo num ambiente preexistente, onde muitas vezes a construção contemporânea destoa do conjunto, interrompe o tecido urbano e desordena o espaço.

Os arquitetos nem sempre conseguem entender $o$ significado da liberdade e da vigilância quando a temática envolve o ato de projetar em um ambiente construído legalmente protegido. Os que conseguem compreender atuam de maneira respeitosa ao limite transformador, garantindo a permanência dos valores adquiridos ao longo da existência do bem, essenciais para a preservação da identidade cultural do lugar.

\section{A arquitetura contemporânea no núcleo primitivo do Centro Histórico}

Ao percorrer as ruas do Centro Histórico de Belém (CHB), pode-se perceber inúmeros exemplos de atitudes profissionais que demonstram a falta de sensibilidade e compreensão da leitura do conjunto, como o edifício sede do Banco Central, inaugurado na década de 1980, anterior à legislação de proteção, e o Espaço Palmeira, inaugurado na década de 2000, quando a legislação de 
proteção já estava em vigor, ambos geradores de grande impacto na morfologia do CHB e seu entorno (Figura 2).

Figura 2 - A) Sede do Banco Central, na Avenida Boulevard Castilhos França, Belém/PA. B) Espaço Palmeira, no bairro da Campina, Centro Histórico de Belém

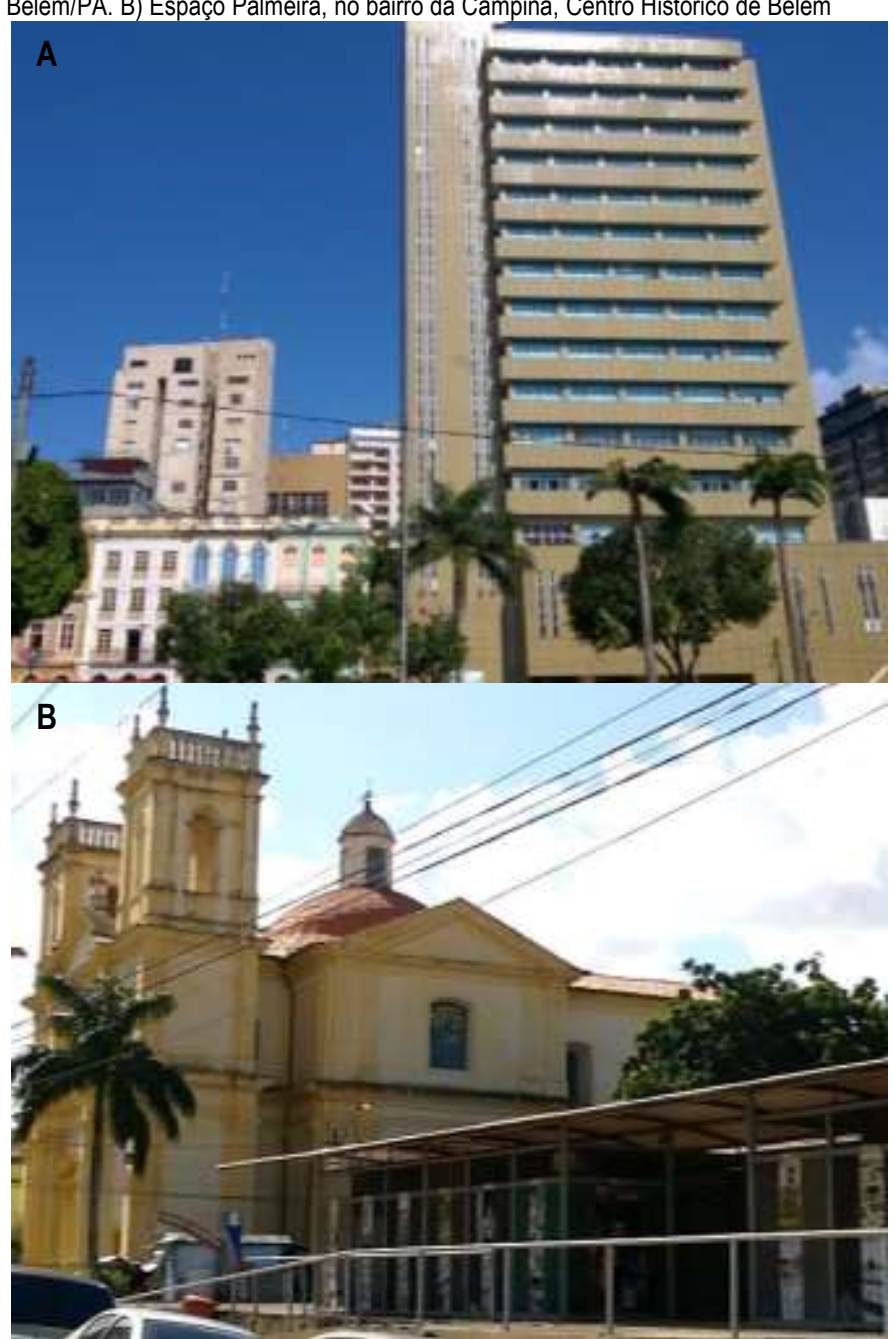

Foto: Márcia Forte (Junho de 2015)

Fica evidente que parte dos profissionais que atuam com intervenções na capital não faz nenhuma reflexão crítica acerca de seus projetos, e outra parte assume postura pautada nos conceitos clássicos, sobretudo os brandianos. Dentro da linha de pensamento de Brandi (2008), ao encarar tanto o edifício de modo isolado como o conjunto como obra de arte, um elemento novo não pode sobressair, nem romper com o contexto, devendo ser absorvido pelo mesmo de forma harmônica e atual.

A partir desse pressuposto, ao analisar uma intervenção deve-se levar em consideração a escolha de alguns elementos de referência, dentre os quais: a volumetria que atua como elemento fundamental da composição adequada ao entorno, a relação entre cheios e vazios, a textura das superfícies, a cobertura, as cores, dentre outros; de modo que a intervenção se apresente em conformidade com $\mathrm{o}$ ambiente $\mathrm{e}$ respeito às preexistências.
$\mathrm{O}$ crescimento da atividade comercial no $\mathrm{CHB}$, aliado ao longo período de ausência de políticas públicas e mecanismos de proteção eficazes, resultaram em um gradativo processo de descaracterização da área. O local, apesar da identidade cultural, possui belos exemplares arquitetônicos que sobrevivem aos processos degradantes do espaço e convivem com a falta de sensibilidade profissional e com o mau uso imposto pelos proprietários.

Além das fachadas, cada vez mais alteradas, sobretudo nos pavimentos térreos, com seus enormes vãos rasgados sob a justificativa de atrair mais consumidores, os pavimentos superiores das edificações são comumente subutilizados como depósitos, e camuflados por painéis publicitários (com estruturas fixadas nas fachadas) que contribuem com uma atmosfera de poluição visual, e que deixam quase oculta a leitura das características tipológicas dos sobrados, alterando a morfologia urbana da área.

Em muitos casos, o valor econômico, fundamental para a preservação das preexistências, se sobrepõe ao valor cultural, e cultua o lucro e a individualidade de algo que deveria ser coletivo. Esse é um dos fatores que mais dificultam a conservação desta que é uma das menores e mais valiosas áreas da cidade.

\section{Ver-o-Peso: Harmonia entre o novo e o antigo}

O Conjunto Arquitetônico e Paisagístico do "Ver-o-Peso" (Figura 3) incluindo: a feira livre, o Mercado de Peixe, Mercado de Carne, Solar da Beira, Feira do Açaí e áreas adjacentes, desde a Boulevard Castilhos França até a Praça D. Pedro II e Praça do Relógio, foi tombado no ano de 1977 pelo IPHAN, e atualmente é considerado um importante elemento de referência cultural para Belém e para o Brasil.

Durante os seus quase quatro séculos de existência, o local passou por várias transformações, umas mais e outras menos significativas, abrangendo o conjunto, ou, em alguns casos, os edifícios de modo isolado. Este artigo não se ocupará das intervenções restaurativas dos edifícios históricos, concentrará a análise nos projetos propostos para a feira-livre, que não se constitui em imóvel, porém é parte importante na leitura do conjunto secular.

\section{As principais intervenções arquitetônicas da contemporaneidade}

A denominação de Complexo Ver-o-Peso surgiu no ano de 1985, quando, após muitas reformas na área, foi inaugurado o projeto de requalificação do conjunto, de autoria do arquiteto Paulo Chaves Fernandes, na época 
coordenador de Arquitetura e Urbanismo da Prefeitura de Belém, com destaque para a nova orla, reorganização da feira, que contaria com novo sistema de padronização das coberturas das barracas, e instalação de nova iluminação.

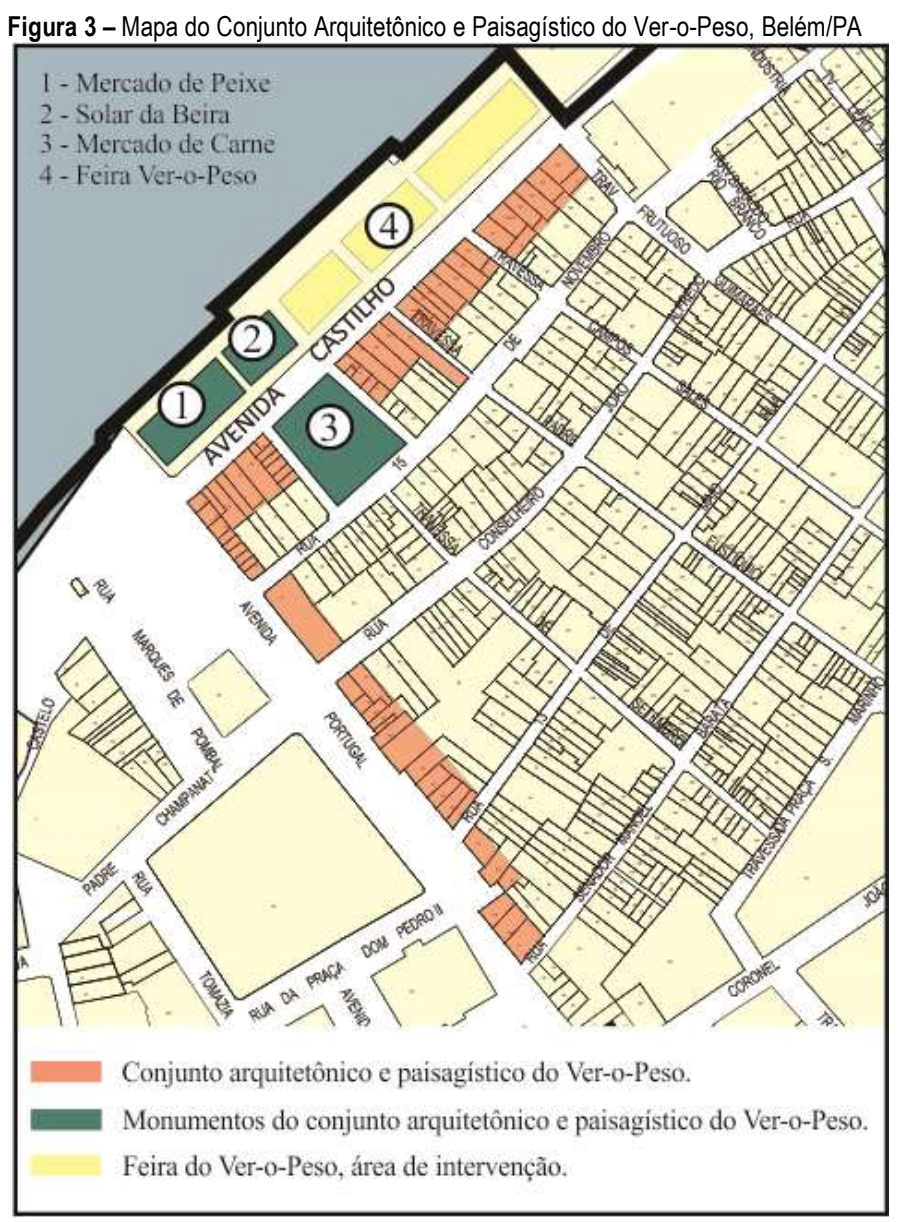

Fonte: Elaborado por Márcia Forte, a partir de arquivo digital da $2^{\text {a }}$ SR/IPHAN/PA

Três anos após a inauguração do Complexo Ver-o-Peso, em 1988, já havia sinais de descaracterização do projeto implantado em 1985, devido a algumas falhas identificadas que terminaram por não atender de modo satisfatório às condições dos feirantes e usuários do espaço, que viriam a improvisar com lonas complementares (Figura 4) as coberturas construídas (O Liberal, 18 de fevereiro de 1988), e pela falta de manutenção, o que terminou afastando a população frequentadora da feira.

Após longo período de abandono e falta de investimentos por parte do poder público, que teve como consequência uma crescente degradação da área, agravada pelo aumento do número de feirantes, a Prefeitura Municipal, junto ao Instituto de Arquitetos do Brasil (IAB), promoveu, em 1998, um concurso público nacional de projetos, na tentativa de reverter a precária situação do local. O concurso para a Requalificação do Complexo Ver-o-Peso foi coordenado por comissão composta pelos arquitetos e urbanistas Milton Monte (PA), Maria
Dorotéa de Lima (PA), Alex Nicolaeff (RJ) e Vital M. T. Pessoa de Melo (PE), que analisaram onze trabalhos, classificando três propostas para a segunda fase, que teve como vencedora a proposta do escritório carioca de Flávio Ferreira.

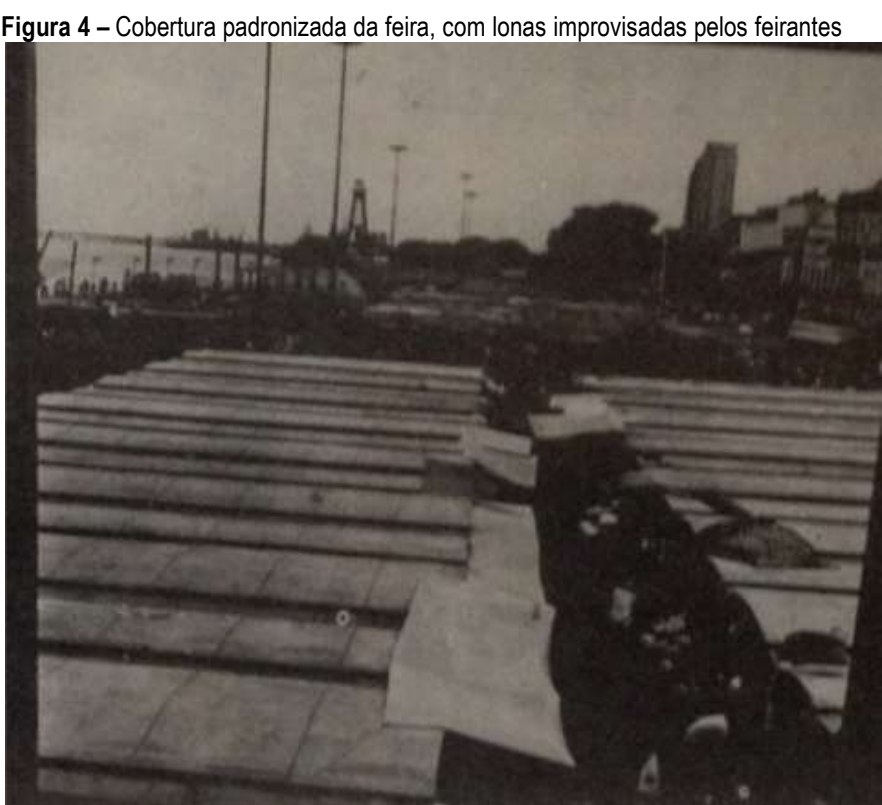

Fonte: Jornal "O Liberal", edição com data de 18 de fevereiro de 1988

Segundo a arquiteta Maria Dorotéa de Lima ${ }^{6}$, membro da comissão, e atualmente superintendente regional da $2^{\text {a }}$ SR/IPHAN, os parâmetros utilizados para julgamento levaram em consideração a melhor solução estéticoprojetual, que preservava as visuais do rio e associava de forma positiva o tradicional ao contemporâneo.

Os autores do projeto vencedor sugeriram ampla participação popular, estimulando a criação de grupos compostos pelos mais diversos segmentos sociais, sem exclusão, como forma de desenvolvimento de cooperação pública e privada no processo projetual. A partir de então puderam contar com a participação da população e dos feirantes, que emitiram opiniões importantes para a tomada de decisões, resultando em um conjunto de ações envolvendo a restauração e readequação das edificações históricas (Mercado de Peixe, Mercado de Carne e Solar da Beira), reordenação da feira com instalação de novo sistema de cobertura, executado com lona tensionada, instalação de novo mobiliário urbano, substituindo as antigas barracas de madeira, e reurbanização de toda a área.

O escritório utilizou como principal fonte de referência a cultura local, representada por manifestações eruditas (estruturas metálicas dos Mercados de Peixe e Carne, o relógio e a praça e o Solar da Beira) e populares (os barcos, os tabuleiros cheios de mercadorias, as estruturas de madeira) que coexistem no Ver-o-Peso. 
O Ver-o-Peso, em sua fascinante tensão entre o erudito $e$ o popular, entre o civilizado e o telúrico, entre o histórico e o contemporâneo, já é amazônico, e se o respeitarmos culturalmente continuará amazônico. ${ }^{7}$

O partido adotado pelo escritório vencedor do concurso estava pautado em duas premissas, segundo o arquiteto Flávio Ferreira, coordenador do projeto: emprestar ao local um ar de contemporaneidade e ao mesmo tempo manter a existência secular do Ver-o-Peso. Numa constante negociação de tensões, os autores se depararam com a estranheza causada por uma inserção contemporânea num dos locais mais icônicos da cidade.

Os arquitetos, a partir do momento em que conseguiram enxergar além do objeto e sua materialidade, explorando sua função e significado, estabeleceram relação com o pensamento intervencionista atual. Ao projetar uma cobertura de lona tensionada para a feira deram ao conjunto um ar contemporâneo, sem agredir o mercado vizinho, chamando a atenção da população, e reforçando a identidade do conjunto como importante cartão-postal de Belém:

\section{Do ponto de vista do patrimônio cultural havia uma busca por solução para o edifício erudito e a proposta da cobertura da feira, de uma certa maneira, era uma resposta atualizada, cem anos depois, do mesmo modo como o Mercado de Peixe em 1901 foi feito, numa tecnologia nova [...] (ARQUITERURAS..., 2013, 32 '26”)}

Durante o desenvolvimento do projeto, além da pesquisa de campo, que incluiu entrevistas com os feirantes e usuários do espaço, foram feitos estudos com modelos tridimensionais, tomando como base fotografias antigas do mercado e da feira, e foram construídos protótipos da lona e tabuleiros no local de modo a testar o seu funcionamento (Figura 5).

\section{O projeto e a percepção do lugar}

Um projeto numa paisagem definida em seu parecer de tombamento como pitoresca não poderia deixar de causar polêmica, reafirmando a dificuldade de percepção da nova arquitetura, inserida no conjunto histórico. Essa resistência, segundo Gracia (1991), é fruto de uma escassez teórica incapaz de debater acerca das inserções contemporâneas nos ambientes preexistentes: "[...] $a$ literatura teórica do nosso século nada elaborou a respeito de como se estabelece a dialética entre nova arquitetura e cidade construída. Aceitou-se, acriticamente, que tal questão é permanente ao longo dos séculos [...]" (GRACIA, 1991, p. 22. Tradução da autora).

É necessário compreender que qualquer intervenção não se limita a um objeto individualmente, influencia e modifica todo o conjunto. No caso do Ver-o-Peso a intervenção foi feita num conjunto tombado, com grande representatividade para a cultura local, e algumas particularidades, tendo em vista que além dos edifícios históricos e casario oitocentista, também abrange a feira com toda a sua dinâmica e desordenamento.

Figura 5 - A) Simulação computacional da proposta vencedora para o Mercado de Peixe e feira, parte do conjunto do Ver-o-Peso. B) Simulação computacional da estrutura das lonas de cobertura da feira.
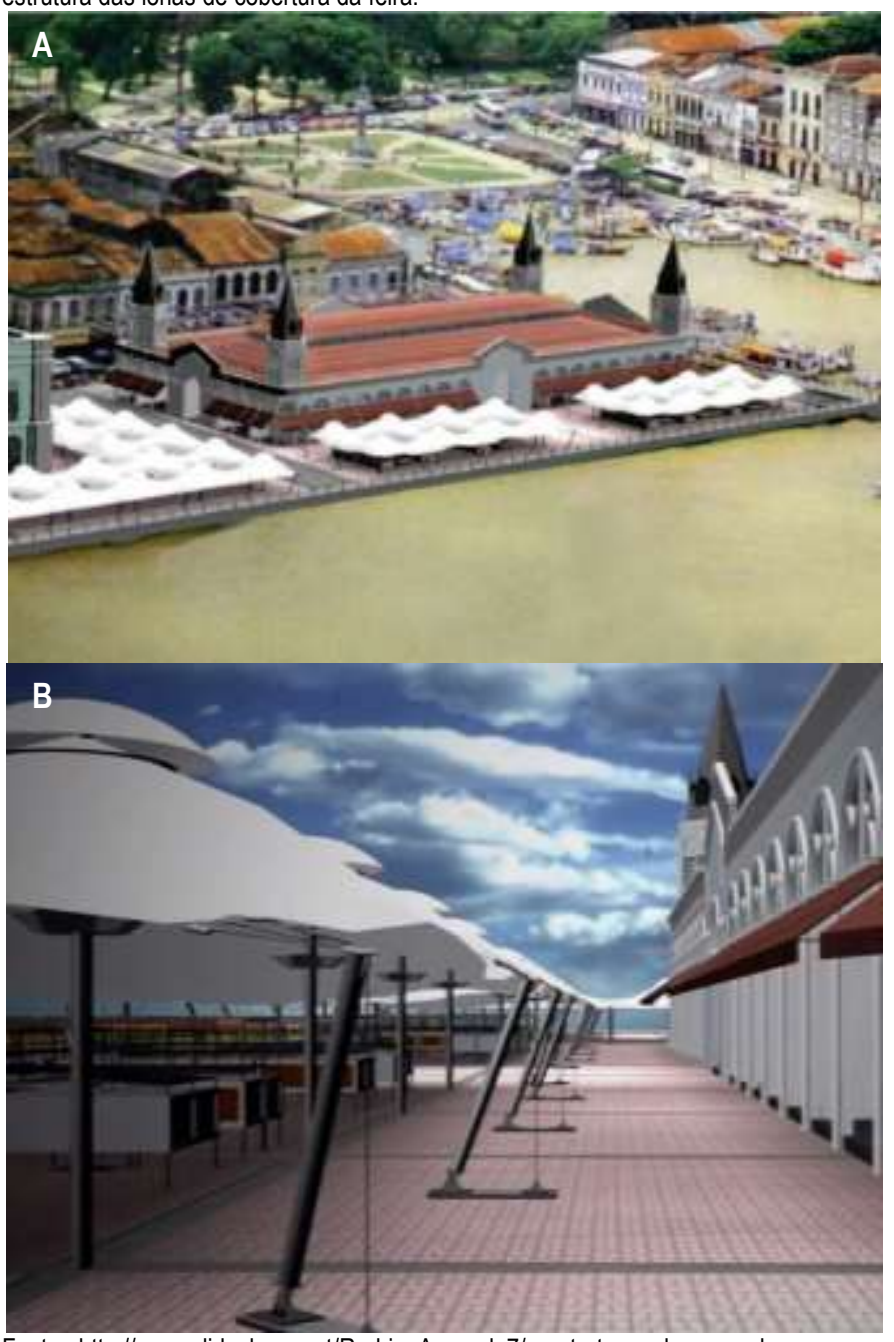

Fonte: http://www.slideshare.net/RodrigoAzevedo7/reestruturao-do-mercado-veropesobelm-do-par. Acesso em 13 de nov. 2014

Um projeto nessa escala termina por envolver uma série de atores, dentre os quais a prefeitura, os órgãos de proteção ao patrimônio, feirantes e a sociedade de Belém de um modo geral, e requer uma capacidade de mediação de conflitos, e de percepção da importante relação do mercado com a cidade. Os arquitetos, ao incluírem o diálogo com esses atores, em especial abrindo espaço aos feirantes, usuários cotidianos do espaço, discutindo diretrizes de melhor funcionamento da proposta, utilizaram como referência a teoria de Kevin Lynch (1960), refutando princípios absolutistas e conservadores do modernismo. Ao acolher a participação ativa do cidadão, o escritório também se aproximou, de forma inconsciente, da doutrina contemporânea de MuñozViñas (2004), que defende o diálogo e 
interdisciplinaridade como caminhos fundamentais a resultados positivos.

Os autores do projeto citam Rossi (1995) como uma das referências, fazendo alusão a cidade como um conjunto de permanências e não-permanências. Ao fazerem analogia ao Ver-o-Peso citam como permanentes os monumentos tombados e como não-permanentes todo o resto, chamando atenção para o ambiente histórico da feira, não passível de flexibilidade.

O projeto, além de bastante lógico e justo, foi capaz de organizar funcionalmente o espaço da feira-livre, além de restaurar o Mercado de Peixe, atraindo a população de volta ao local, e dando subsídios à sua conservação. No local existiam barracas, que, apesar de terem passado por intervenções, não atendiam a demanda exigida. A proposta vencedora do concurso foi capaz de resgatar o valor do mercado-feira, devolvendo a cidade um local que mantém sua função original há quase quatrocentos anos (Figura 6).

A contemporaneidade e leveza das lonas não anularam as linhas marcantes do Mercado de Ferro, não houve obstrução visual aos monumentos vizinhos, nem rompimento com a escala do conjunto existente. Pelos motivos citados o conjunto da obra não causou impacto urbano ao ambiente construído, representando uma intervenção positiva para a cidade, e estabelecendo-se como parte importante da identidade do local.

A dinâmica da feira do Ver-o-Peso constitui elemento predominantemente original, sobrevivendo às transformações econômicas, políticas e sociais, e conseguindo manter seu uso primitivo, se reafirmando como um dos principais entrepostos comerciais da cidade. O projeto de intervenção executado, que faz parte da atual paisagem arquitetônica e urbana da área, também teve uma enorme representatividade para a arquitetura das feiras, por conseguir manter o Ver-o-Peso organizado por um longo período, pela primeira vez.

Apesar de representar uma intervenção positiva por se harmonizar com o entorno de forma contemporânea, o projeto possui pontos negativos, no tocante à falta de funcionalidade dos boxes, deficiente conforto térmico para usuários do espaço, dificuldade na manutenção das lonas e custos.

\section{Sesc Boulevard: Da preservação exterior à transformação interna}

O imóvel que hoje abriga o Centro Cultural Sesc Boulevard faz parte da área de entorno do Conjunto Arquitetônico e Paisagístico do Ver-o-Peso, tombado em esfera federal (IPHAN), e está inserido dentro da área do Centro Histórico de Belém, sendo considerado pelo poder público municipal (DPH/Fumbel) como bem de interesse a preservação, sob a classificação de preservação parcial.

Figura 6 - A) Vista da feira do Ver-o-Peso com Solar da Beira e Mercado de Peixe ao fundo, em 1985. B) Vista da feira do Ver-o-Peso após a intervenção, com Solar da Beira e Mercado de Peixe ao fundo, em 2004.

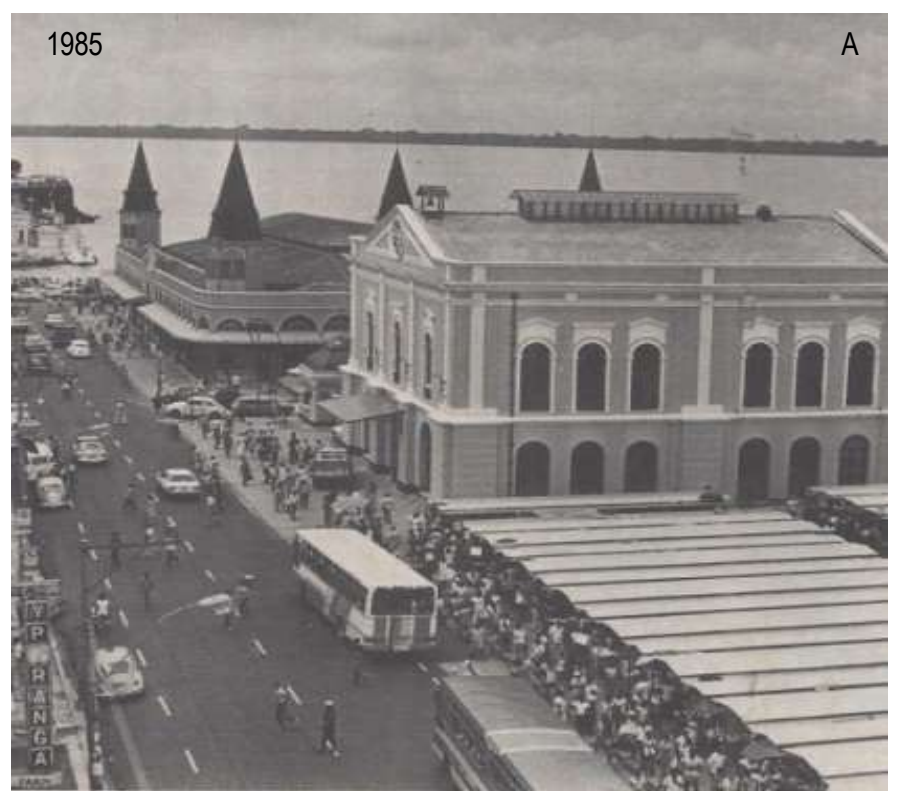

2004 B

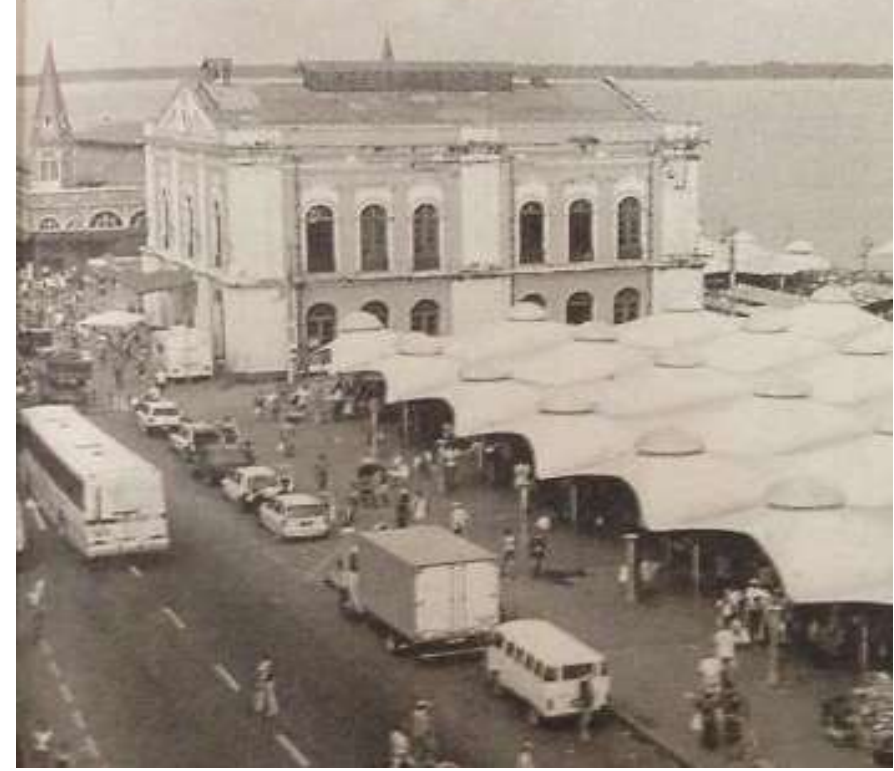

Fonte: A) Jornal "O Liberal", edição com data de 18 de fevereiro de 1985. B) Jornal "O Liberal", edição com data de 16 de abril de 2004.

A edificação, que se constitui numa importante permanência como elemento histórico integrante da paisagem urbana componente do skyline frontal da cidade, passou por longo período de abandono que ocasionou intenso desgaste. Esta situação foi agravada por um incêndio no final da década de 1980, que comprometeu sua estrutura interna e deixou como testemunhos apenas a fachada frontal da Avenida 
Boulevard Castilhos França e a fachada posterior da Rua Gaspar Viana (Figura 7).

Figura 7 - A) Vista da fachada externa (Av. Boulevard Castilhos França), antes da intervenção. Data: 2001. B) Interior do sobrado antes da intervenção. Data: 2001.

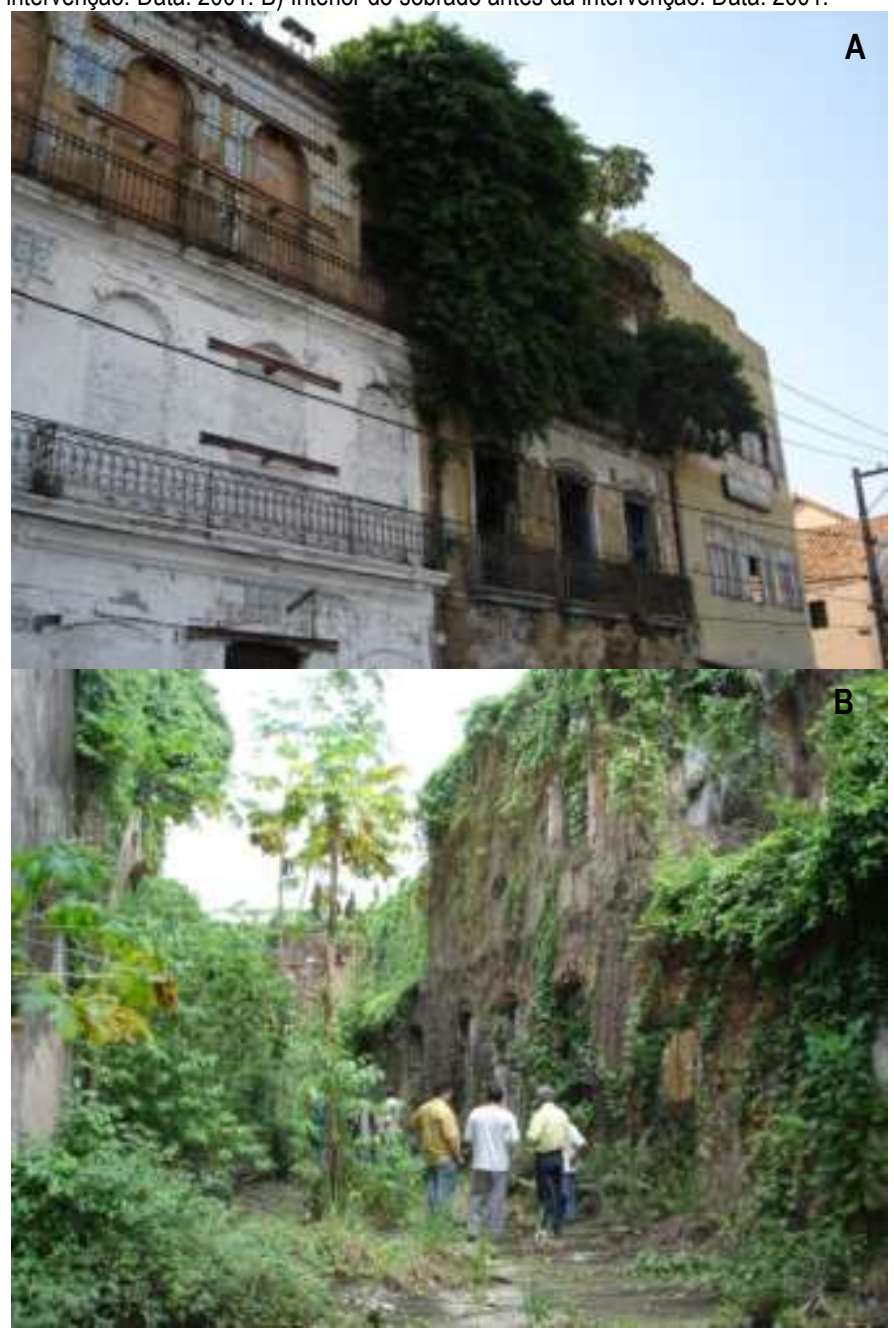

Fonte: Acervo digital da arquiteta Roseane Norat

\section{O projeto}

Comprado pelo Serviço Social do Comércio/Sesc, o imóvel passou por um projeto de intervenção em 2002, elaborado por escritório local - Escala Três Arquitetura -, com o objetivo de requalificá-lo de modo a atender às necessidades do proprietário, permanecendo incorporado harmonicamente ao casario do conjunto histórico. A intervenção proposta reproduz o nível que Gracia (1991) categoriza como modificação circunscrita, a partir do momento em que está restrita ao edifício de modo isolado, que passa por uma ampliação moderada e transformação da estrutura interna.

O projeto partiu da análise do objeto de modo isolado, e sua relação com o casario adjacente, que representa uma importante referência histórica para a cidade, de modo a estabelecer a recuperação do edifício dentro daquela unidade, visando o resgate da leitura da identidade do conjunto urbano. A proposta teve como desafio, além da reutilização dessa importante preexistência, adequá-la ao programa de necessidades de um espaço de eventos e exposições.

De acordo com a arquiteta Roseane Norat ${ }^{8}$, uma das autoras do projeto, inicialmente foram realizadas pesquisas iconográficas, que demonstraram os inúmeros processos de desenvolvimento da edificação, e determinaram um dos principais parâmetros norteadores da proposta de intervenção: o reconhecimento da importância histórica do edifício e sua correlação com o desenvolvimento urbanístico da cidade, originando uma conduta consciente do que merecia ser preservado e do que poderia ser transformado, atendendo à proposição do novo uso.

Externamente as fachadas foram restauradas, a partir da recuperação dos azulejos remanescentes e da complementação das lacunas com réplicas, de modo a reestabelecer a leitura da identidade da vizinhança (Figura 8). A vedação superior foi considerada em termos de conjunto, acompanhando o sentido das águas do telhado das edificações históricas daquela tipologia e os materiais de cobertura (telhas cerâmicas tipo capa e canal) dos sobrados adjacentes, porém rompendo de forma discreta, visível apenas em ângulo acima do nível do observador localizado na via pública. Trata-se ainda de intervenção que marca sua atualidade com o uso de claraboias.

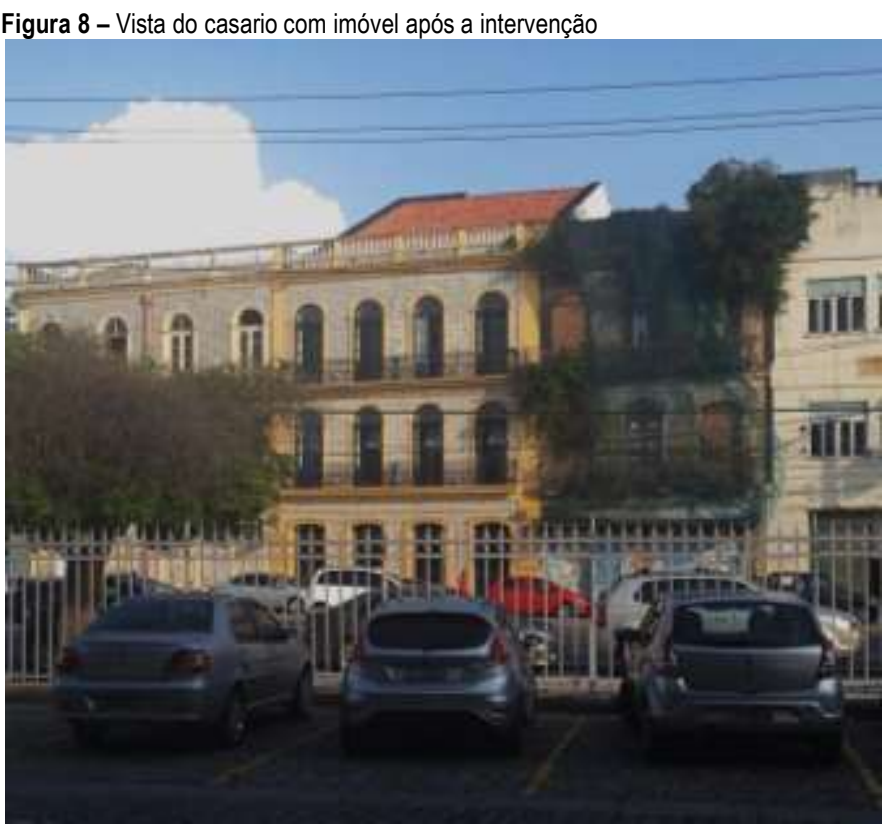

Foto: Márcia Forte (Outubro de 2014)

Internamente buscou-se respeitar as estruturas remanescentes, utilizando-se materiais contemporâneos, sempre correlacionados com os sistemas tradicionais. Foram executadas novas lajes, substituindo as que haviam sido perdidas, e pilares metálicos nas 
extremidades, interligados por vigotas metálicas, explorando como referência o antigo sistema de barroteamento.

Transformado em um espaço de estímulo e incentivo à cultura, por meio de atividades ligadas à música, artes plásticas, teatro, dança e literatura, o Centro Cultural Sesc Boulevard representa hoje um importante espaço de fomento à cultura da cidade, com galeria, auditório e área para eventos. O nível térreo, com entrada pela Avenida Boulevard Castilhos França, abriga o acesso principal e uma galeria para exposições de arte; no primeiro pavimento funciona um bar/café, auditório e sanitários; no segundo pavimento estão instalados um salão de eventos, administração e apoio, com um pequeno salão de eventos e depósito no mezanino (Figura 9).

Figura 9 - Plantas do projeto: A) Pavimento térreo; B) $1^{\circ}$ pavimento; C) $2^{\circ}$ pavimento; D) Mezanino

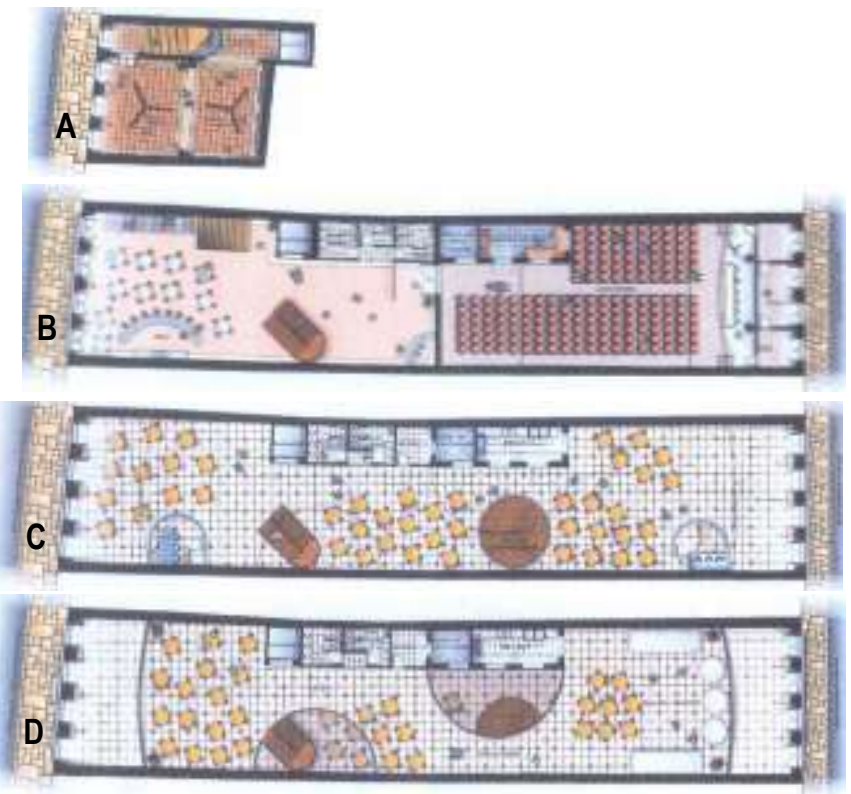

Fonte: Acervo digital da arquiteta Roseane Norat

\section{Proposta atual e o respeito à ambiência urbana}

Ao citar as referências teóricas que embasaram o projeto, a arquiteta Roseane Norat menciona os teóricos Riegl e Brandi como principais fontes. Faz alusão a Riegl (2013) quando afirma que qualquer decisão de projeto ou de obra tem uma implicação e privilegia determinado valor do edifício em detrimento de outro, e reforça a necessidade de profundo conhecimento do bem e de seu entorno como balizadores de definições conscientes. Ao se reportar a Brandi (2008), indica forte influência de seus axiomas na tomada de decisões e interpreta o conjunto edificado como unidade artística. Opta por uma estrutura visivelmente contemporânea, com o cuidado necessário para que a mesma comprometa minimamente as edificações contíguas que possuem paredes geminadas, o que demonstra uma responsabilidade com as edificações circunvizinhas.

O projeto pode ser caracterizado como uma intervenção de caráter moderado, assumindo características positivas como um projeto contemporâneo que, ao entender o conjunto como uma unidade artística, demonstra respeito à preexistência ao restaurar a estrutura remanescente das fachadas. Ao mesmo tempo, rompe conscientemente e inova com o uso de claraboias na cobertura, na tentativa de aproveitamento de luz natural dentro de um casco histórico. Vai além quando desenvolve novas plantas a partir de leituras de elementos da edificação, sem gerar dúvidas a respeito do que é antigo e do que é novo.

Outro importante aspecto de contemporaneidade foi a adequação à acessibilidade por meio da instalação de um elevador no interior do edifício e a adoção de conceitos de sustentabilidade, com a utilização de sistemas de captação de águas pluviais, pensados com uma reserva para captação de águas de chuva e todo um sistema elétrico de bombeamento que, na ausência ou diminuição das chuvas, passa a ser alimentado pelo sistema público, e representa algo ainda pouco habitual nas intervenções arquitetônicas da cidade.

A tomada de decisão com relação à fachada azulejada levou à remoção dos poucos azulejos históricos. As réplicas assumiram maior destaque por estarem localizadas no campo visual das pessoas, em detrimento dos azulejos originais, aplicados na parte superior do imóvel. A intervenção na fachada azulejada do SESC Boulevard influenciou equivocadamente a substituição de azulejos históricos, semi-industriais e com retoques manuais, por réplicas com azulejos industriais na fachada vizinha, que estava quase na sua totalidade preservada.

\section{Edifício Bechara Mattar: 0 desafio quando a preexistência já representa um equívoco}

O Edifício Bechara Mattar está inserido no núcleo primitivo do Centro Histórico de Belém, cercado pelos primeiros monumentos tombados pelo Governo Federal (Igreja da Sé e Igreja de Santo Alexandre), que fazem parte do Conjunto Arquitetônico e Paisagístico da Praça Frei Caetano Brandão, constituindo também área de entorno do Conjunto Arquitetônico e Paisagístico do Vero-Peso.

No local existia um casario (Figura 10A), demolido no final da década de 1960, na época desprotegido legalmente, para a construção do edifício Bechara Mattar. A ausência dos sobrados descaracterizou a morfologia do conjunto, que passou a conviver com um edifício que viria a gerar uma considerável interferência na escala e 
configuração da paisagem, com proporções bastante agressivas à área.

Em 1999 um incêndio destruiu a loja de fogos de artifício Bechara Mattar, que funcionava no pavimento térreo do imóvel, ameaçando atingir monumentos vizinhos, e levantando um debate acerca do uso em edifícios inseridos em áreas históricas. A partir de então o edifício nunca mais foi ocupado, e seu esqueleto estrutural permanece abandonado até os dias de hoje (Figura 10B).

Figura10 - A) Largo da Sé com indicação de casario demolido no final da década de 1960. Foto sem data. B) Largo da Sé com estrutura do edifício Bechara Mattar após incêndio (2010)

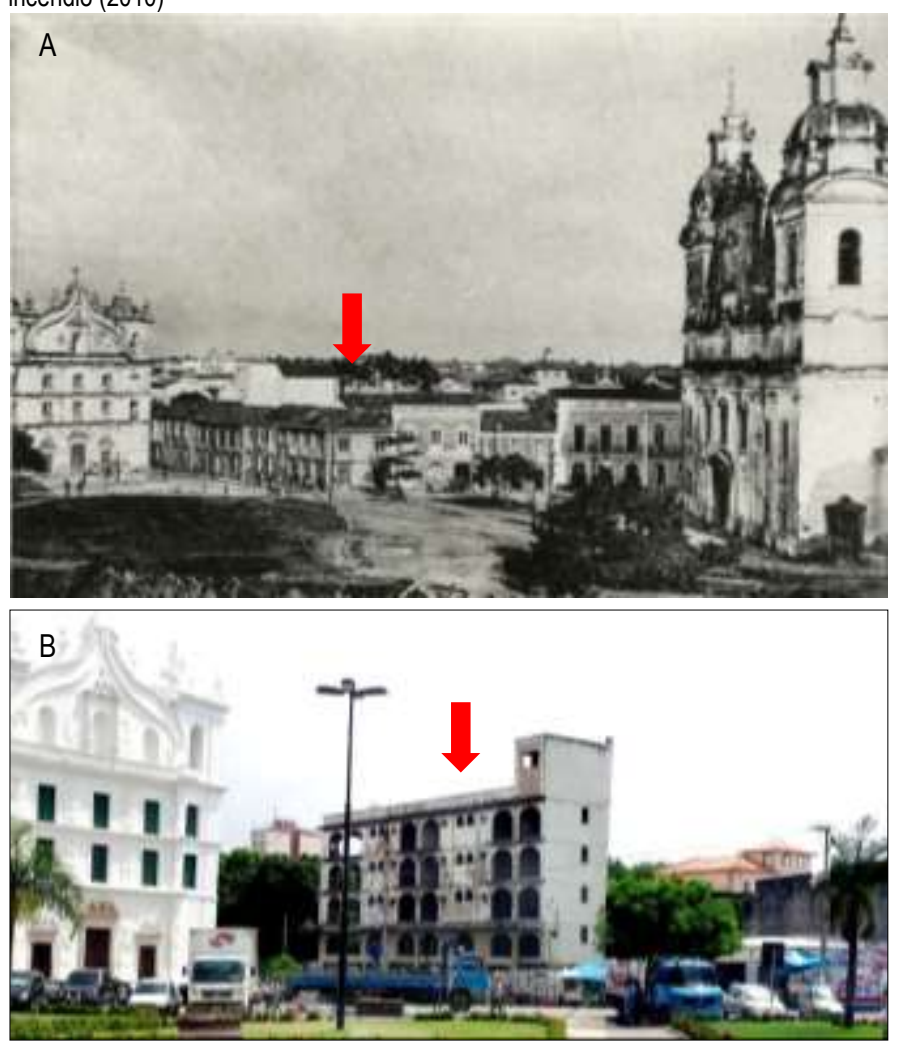

Fonte: A) Álbum de Cacavoni. B) Acervo Flávio Nassar

\section{A nova transformação}

Em 2010 um escritório de arquitetura local, coordenado pelo arquiteto Paulo Chaves Fernandes, foi contratado pelos proprietários do imóvel para elaborar um projeto para o edifício e dois lotes adjacentes ao mesmo, constituindo três intervenções conceitualmente diferenciadas. A primeira intervenção corresponde à reforma do prédio existente e sua adaptação a variações de uso. A segunda intervenção representa a construção de um volume anexo, em terreno vazio ao lado da edificação existente. Finalmente, a terceira intervenção propõe a requalificação de um imóvel contíguo ao edifício moderno, pela Rua Tomázia Perdigão, que ainda guarda resquícios de sua arquitetura original.
A primeira intervenção citada, referente à reforma do edifício moderno Bechara Mattar, levanta um questionamento acerca de como proceder em casos semelhantes, visto que o edifício existente já representa uma agressão ao entorno. $\mathrm{O}$ fato de ter sido construído antes da legislação assegurou ao proprietário o direito de manter o gabarito existente, não sendo obrigado a demolir o imóvel. Além disso, o edifício é classificado pela Fundação Cultural do Município de Belém (FUMBEL), por meio da Lei de Proteção 7.709/94, como bem de Renovação Arquitetônica, categoria que inclui imóveis sem valor histórico ou interesse a preservação, podendo ser demolidos ou modificados, de modo a estabelecer uma relação harmônica com o contexto urbano onde estão inseridos.

Diante desse pressuposto, e visando um maior aproveitamento da área existente, os arquitetos responsáveis pelo projeto optaram por manter a estrutura remanescente. A partir de então, propuseram uma requalificação arquitetônica, que inclui a renovação da fachada e, internamente, algumas alterações estruturais para a adaptação ao novo uso, sob o argumento de que o projeto teve como base pesquisas e leitura dos códigos morfológicos da área em que se insere.

Projeto semelhante foi executado no imóvel 26/28 da Praça da Sé, em Salvador, no ano de 2010, quando um escritório de arquitetura foi contratado para apresentar proposta que viesse a amenizar uma intervenção inadequada realizada no imóvel na década anterior. $\mathrm{O}$ projeto precedente teve como base uma interpretação equivocada de sobreposição e destaque do novo, refletindo em uma descontinuidade arquitetônica com relação aos vizinhos antigos e em grande impacto negativo ao conjunto (Figura 11A). Após esta intervenção, o edifício ficou popularmente conhecido como "forno de micro-ondas".

Diante da impossibilidade de resgate da imagem do edifício antigo, o que representaria um pastiche, a nova proposta criou um edifício contemporâneo contextualizado, que buscou elementos comuns no entorno, tais como a relação de cheios e vazios, ritmos dos vãos, texturas e cores. Com o uso de tecnologia e materiais atuais, a intervenção devolveu uma imagem homogênea e harmoniosa ao conjunto, corrigindo o equívoco que fez parte da paisagem arquitetônica da Praça da Sé durante quase uma década (Figura 11B).

No caso do edifício Bechara Mattar, o esqueleto estrutural existente (Figura 12), remanescente de projeto da década de 1970, descaracteriza agressivamente o entorno, e a elaboração de uma proposta para o local representa a possibilidade de correção desse equívoco, de forma a minimizar os efeitos de contraste do prédio com relação ao conjunto. De acordo com o memorial 
descritivo do projeto $^{9}$, o uso desse volume será comercial, com lâminas corporativas, e refeitório no último pavimento, que receberá uma cobertura de vidro com estrutura metálica.

Figura11 - A) Edifício popularmente batizado de "forno de micro-ondas", no Largo da Sé, Salvador/BA. B) Edifício "forno de micro-ondas" após projeto de intervenção executado em 2010
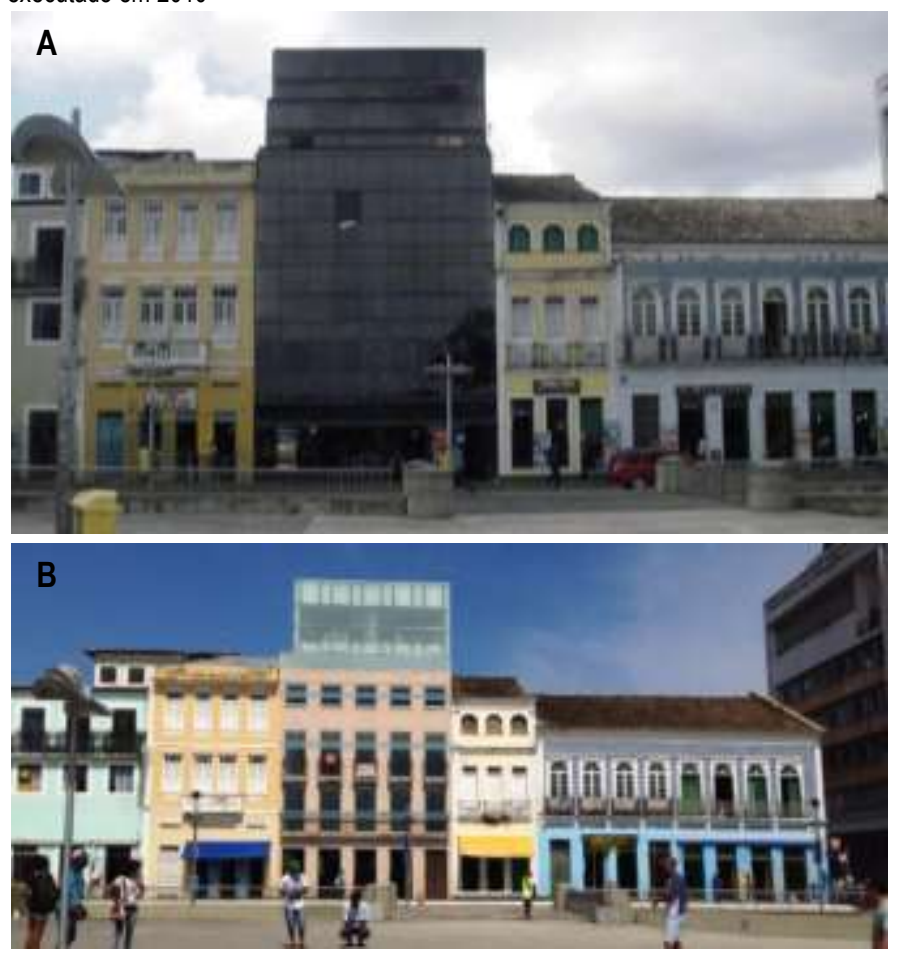

Fonte: A) www.docexpoe.com. Acesso em 26 de junho de 2015. B) Foto: Renata Gribel (Agosto 2015)

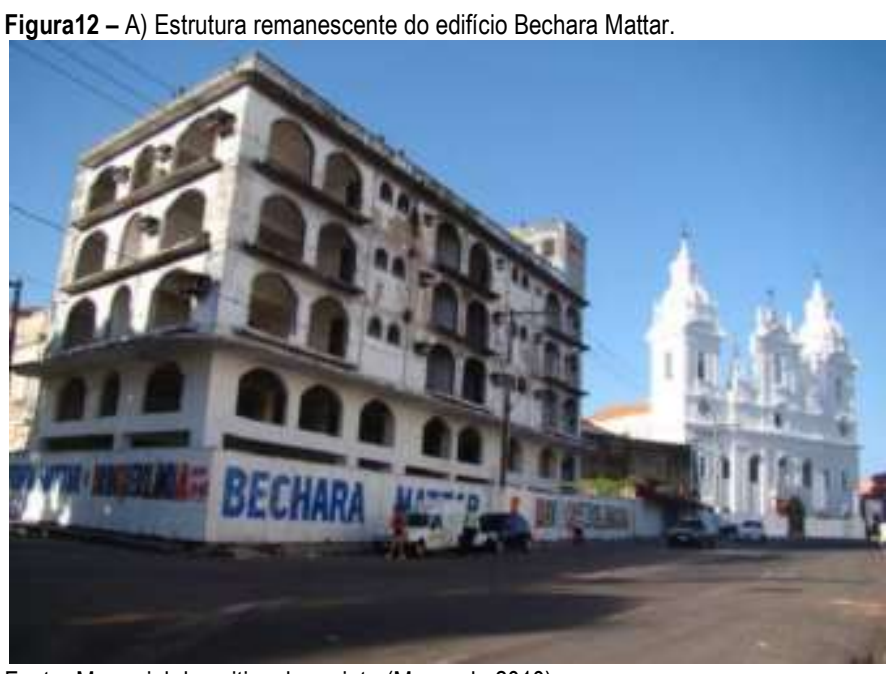

Fonte: Memorial descritivo do projeto (Março de 2010)

A nova construção proposta para o anexo ao edifício Bechara Mattar abrigará um estacionamento, áreas técnicas, uma área de convivência e, no último pavimento, uma praça. Foi projetada com altura de 8,85 metros, excedendo em 1,85 metros a altura máxima permitida de acordo com a Lei 7.709/94. Os arquitetos defendem o excedente em altura como uma forma de minimizar o impacto observado diante da presença do edifício principal ao confrontar-se com o conjunto.

A terceira intervenção proposta para o "complexo" corresponde a um projeto de requalificação arquitetônica com alteração de uso, no imóvel vizinho, na Rua Tomázia Perdigão, um edifício eclético de interesse à preservação. Nesse local funcionará um hotel de pequeno porte, com apenas seis apartamentos. O projeto prevê a restauração da fachada principal e recomposição dos vãos, reconstituição da cobertura e claraboia. Os autores justificam como embasamento teórico que norteou a intervenção o princípio da autenticidade ${ }^{10}$.

Após a elaboração do projeto, este foi encaminhado aos órgãos competentes, responsáveis pela preservação do patrimônio cultural de Belém, e teve parecer aprovado em todas as instâncias - municipal, estadual e federal. De acordo com o parecer, emitido pelo IPHAN em $2010^{11}$, o imóvel em questão não apresenta características pretéritas de interesse à preservação e as modificações previstas para a sua volumetria externa não geram interferência na visibilidade e ambiência do entorno.

\section{As repercussões de uma nota publicitária no jornal}

O projeto desde 2013 vem sendo alvo de muita polêmica, numa discussão que vai além do cunho teórico-projetual. Por ter sido veiculada na imprensa, sob o nome de Bechara Mattar Diamond, a requalificação do edifício, que, segundo nota em jornal, abrigaria um Shopping Center, veio a provocar uma enorme manifestação contrária por parte dos moradores da Cidade Velha, arquitetos e frequentadores da área, tendo como foco o citado uso para o edifício, que ocasionaria um enorme impacto à área.

Em outubro do mesmo ano foi realizada uma audiência pública no Ministério Público Federal, tendo como pauta o projeto de requalificação para o citado edifício. $\mathrm{O}$ projeto elaborado foi bastante criticado, pela falta de ambiência com o entorno e por gerar grande impacto à vizinhança local.

O Conselho dos Arquitetos e Urbanistas (CAU/PA) criticou os pareceres elaborados pelos órgãos locais de preservação, que aprovaram o projeto em 2011, e elaborou um parecer, com base no que foi divulgado em nota publicitária. $\mathrm{O}$ documento chamou a atenção para a visível interferência causada pelo imóvel de esquina na escala e configuração da paisagem da área, por representar destaque pelas suas proporções e gerar contraste quando confrontado com a escala das edificações existentes em seu entorno imediato.

O parecer do CAU/PA cita a ampliação defendida pelos órgãos de proteção como "ampliação de uma 
desconformidade", e argumenta que a mesma fere ainda mais os parâmetros legais estabelecidos. Sobre a construção do anexo afirma que a altura deste conflita com o disposto na Lei 7.709/94, que estabelece gabarito de sete metros para a área. Ao abordar a relação entre os cheios e vazios da fachada do prédio modernista, argumenta existir um rompimento de escala e ritmo da composição do conjunto de fachadas, considerando assim que o projeto apresentado não reinsere o edifício ao contexto urbano da área.

A relação de cheios e vazios nas fachadas das edificações mudou ao longo dos anos. No século XVIII a proporção de cheios era muito maior do que a de vazios, já no século XIX essa proporção é invertida. Esse entendimento é fundamental para orientar as análises técnicas acerca do impacto visual que a nova arquitetura terá no contexto histórico. Uma intervenção que leva em consideração as relações tipológicas das edificações preexistentes do entorno não necessariamente precisa repetir as dimensões dos vãos e das vedações. É preciso entender o ritmo e harmonia dessas aberturas e aplicar isso em uma linguagem contemporânea, atual e elegante para com o contexto em que está inserido.

A pura e simples imitação do antigo, mesmo que seja apenas com a repetição de vãos em dimensão e forma, causa confusão e pode resultar em falsos históricos e, portanto, equívoco conceitual do passado, quando as intervenções não eram um ato crítico, remetendo a conduta comum em Belém, principalmente na década de 1980. Porém, em pleno século XXI espera-se a superação desta prática. Um exemplo interessante da boa convivência, harmônica, de diálogo entre arquiteturas, é o casario da Cruz do Pascoal, em Salvador, onde observase uma edificação Art Deco convivendo harmonicamente com outras coloniais e ecléticas. Os vãos não têm a mesma altura, mas se observa que a leitura é mantida, pela continuidade de frequência e forma dessas aberturas (Figura 13).

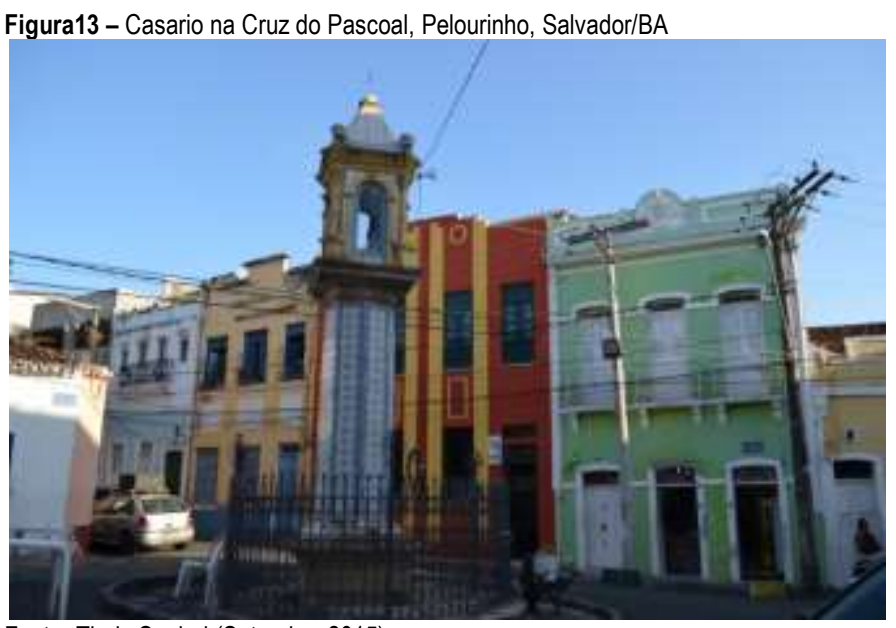

Fonte: Thais Sanjad (Setembro 2015)
A polêmica e pressão em torno do projeto resultaram em novo pedido de análise por parte dos órgãos competentes, e alguns embates acerca da construção de uma cobertura translúcida na parte descoberta do sexto pavimento, que deixa o edifício com altura de quase dezenove metros, da cobertura-jardim do edifício anexo, dentre outras questões, fazendo com que o processo ainda não tenha sido concluído, e o esqueleto estrutural existente no local, continue a fazer parte da realidade do conjunto.

\section{A análise}

As três intervenções, que partem de situações distintas, e, portanto, com diferentes características conceituais, compõem o projeto denominado Complexo Empresarial Bechara Mattar (Figura 14), e têm muito a acrescentar ao debate acerca da influência do projeto como fundamental a preservação de uma área histórica tão importante, fomentando sua manutenção e reafirmação como patrimônio cultural, na constante dinâmica de desenvolvimento da cidade.

Com relação às referências teóricas determinantes à tomada de decisões, os autores do projeto afirmam que buscaram a fundamentação teórica em Brandi (2008), não individualizando, porém, o prédio existente, mas observando o sítio inaugural da cidade como um conjunto, detentor da unidade potencial da obra de arte.

Brandi (2008) é considerado um dos mais importantes teóricos do restauro, tido como responsável por dar embasamento a inúmeros projetos de intervenção até os dias de hoje. $\mathrm{O}$ autor também enfatiza que a restauração constitui o momento do reconhecimento da obra de arte, cita sua materialidade e sua importância estética e histórica, com efeito à sua transmissão às gerações futuras.

Nesse caso, a preexistência, agressiva e descaracterizante pela sua ruptura com o contexto, não deve ser analisada como balizadora de decisões, e sim o entorno imediato, detentor de notável significância cultural por representar o núcleo primitivo da cidade. Ao manter o esqueleto existente e acrescentar ao mesmo um pavimento útil, a proposta reafirma a interferência frente ao critério da visibilidade. Por outro lado, ao se afirmar como um projeto atual, desenvolvido com materiais e técnicas modernas, reforça um caráter positivo e foge do pastiche ao se lançar à polêmica e se assumir como um edifício do século XXI e, portanto, um legítimo projeto contemporâneo.

Ao representar a possibilidade de dar um novo uso ao edifício, há anos abandonado, a partir de uma intervenção contemporânea, o projeto abre uma série de discussões acerca de como proceder em prol da coexistência harmônica entre a arquitetura pré-existente e 
contemporânea, destacando a ambiência e o conjunto paisagístico como elementos tão importantes quanto o edifício isoladamente. No entanto, trata-se de uma proposta em edificação que já é impactante e descaracteriza o contexto que está inserida.

Figura 14 - A) Estrutura remanescente do edifício Bechara Mattar, vista do Largo da Sé. B) Simulação computacional do projeto para o Complexo Bechara Mattar, vista do Largo da Sé. C) Estrutura remanescente do edifício Bechara Mattar, visto da Rua Padre Champagnat. D) Simulação computacional do projeto para o Complexo Bechara Mattar, visto da Rua Padre Champagnat
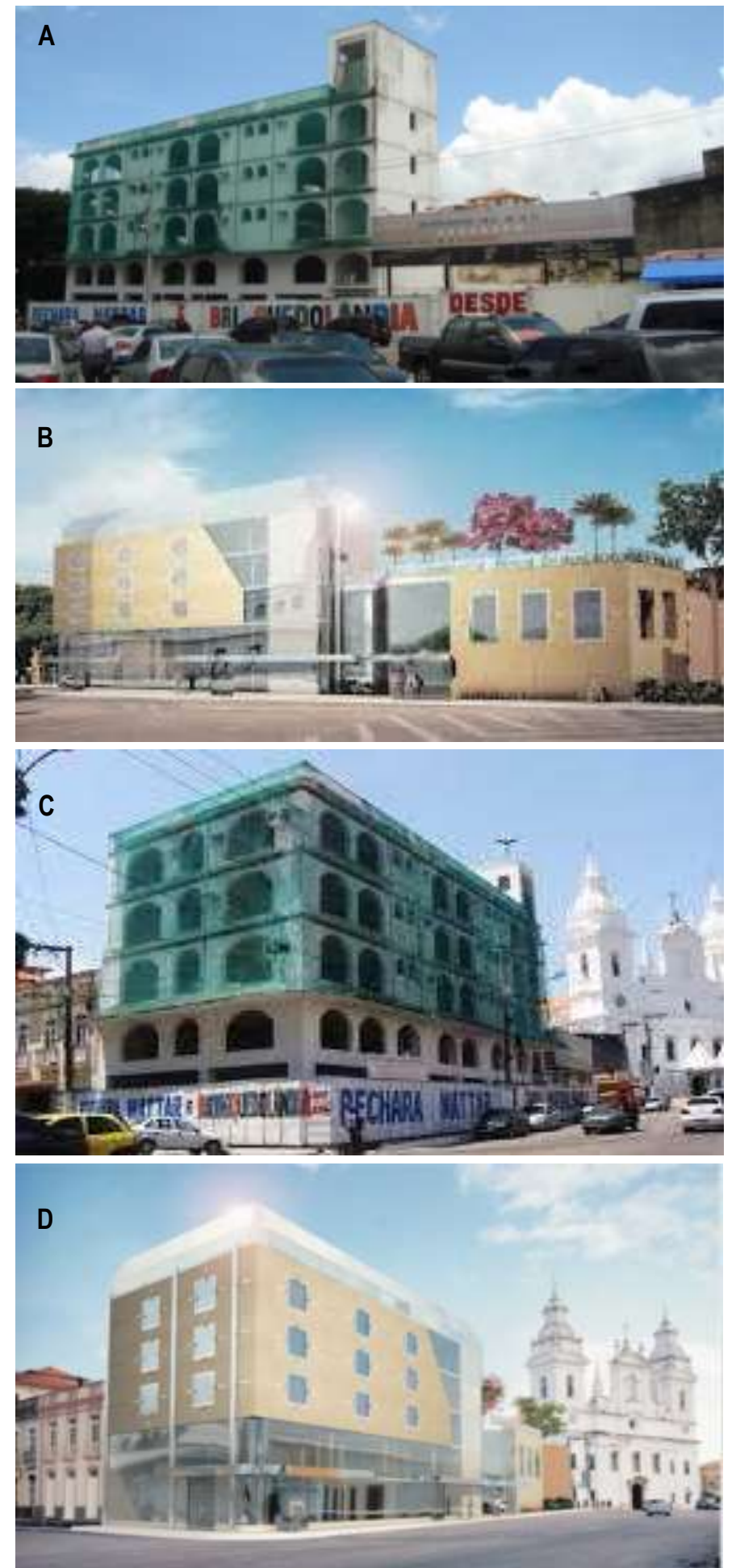

Fonte: Acervo cedido pelo escritório Paulo Chaves Fernandes Arquitetura, responsável pelo projeto
O projeto possui potencialidades, quando, ao estabelecer novo uso ao conjunto, que inclui a restauração de imóvel eclético, requalifica uma estrutura abandonada há quase vinte anos, e preenche uma lacuna existente, através da construção de um anexo, além da sua própria afirmação como arquitetura contemporânea dentro de um Centro Histórico tombado. Chama atenção pela relação de cheios e vazios estabelecida nos andares superiores, que dialoga com o entorno, porém é rompida no pavimento térreo, que possui vedação translúcida. Além disso, o projeto envolve profissionais atuantes na preservação do patrimônio cultural da cidade.

A discussão a respeito do uso das cores como diretriz projetual num conjunto preexistente é um ponto importante a ser considerado. A estrutura remanescente do prédio há alguns anos foi pintada de branco, e, durante esse período, causou um menor desconforto visual ao amenizar o contraste com o entorno imediato, onde as edificações vizinhas, Catedral da Sé e Igreja de Santo Alexandre, também são brancas. Quanto mais clara for a tonalidade dos materiais de acabamento da nova arquitetura, menor impacto visual causará neste entorno predominantemente claro. Se a afirmação enquanto arquitetura contemporânea representa um ponto positivo, por outro lado, o arquiteto precisa considerar que a atualidade do projeto tem que harmonizar com os edifícios que conferem ao lugar o caráter especial de patrimônio cultural. No caso do Bechara Mattar, trata-se de um imóvel de esquina, com grandes dimensões e localização em evidência em relação aos edifícios culturais (Igreja da Sé e Igreja de Santo Alexandre), em lugar fortemente historicizado, núcleo primitivo da cidade de Belém (Figura 15).

Figura15 - Vista aérea do largo da Sé, com destaque para a área do projeto

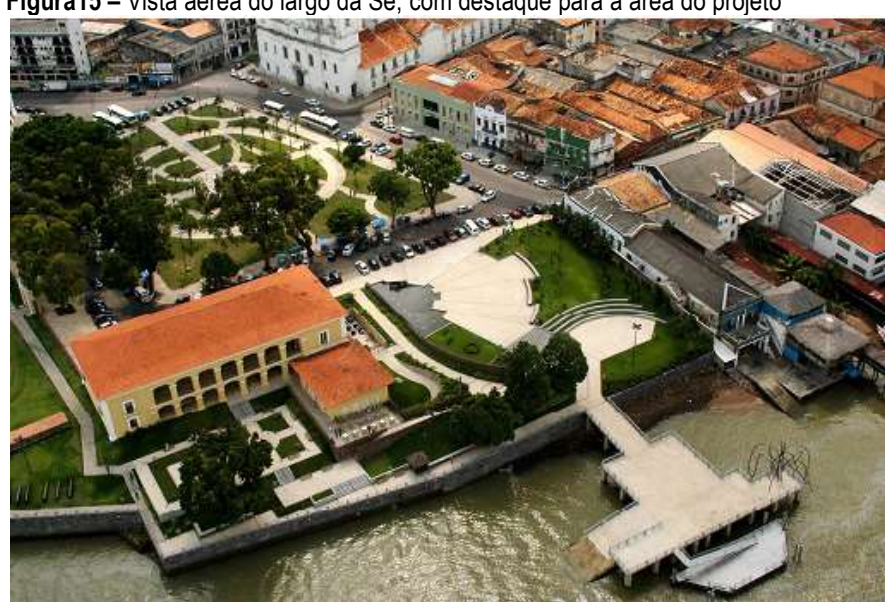

Fonte: Acervo cedido pelo escritório Paulo Chaves Fernandes Arquitetura, responsável pelo projeto. Foto: João Ramid

Qualquer intervenção na estrutura remanescente do Bechara Mattar será automaticamente destacada no seu contexto urbano, porque isto é uma condição preestabelecida, resultante da intervenção 
descompromissada na década de 1970 com a preservação da ambiência urbana quando o mesmo foi construído. Trata-se assim de um grande desafio para os projetistas, um dos maiores no Centro Histórico de Belém, que requer sensibilidade e muita criatividade, pois existe uma clara percepção de conflito entre o passado e o futuro.

Se KafKa tem dois adversários, um que não permite que ele recue e outro que não possibilita que ele avance (ARENDT, 2000) e ambos o ajudam na luta contra o outro, o arquiteto tem que ter aliados para a sua criação, precisa enxergar a preexistência e a transformação como elementos constituidores do lugar, guardadas as devidas restrições em relação às diferentes áreas que compõem o espaço urbano. No caso do centro histórico, lugar de memória, fortemente vinculado à identidade cultural de uma sociedade, a permanência deve guiar a transformação. $\mathrm{O}$ arquiteto precisa buscar o equilíbrio entre passado e futuro a partir da sua criação contemporânea, pois se o presente se impuser, será mais um adversário à preexistência.

No caso do Bechara, e de tantas outras edificações que descaracterizam o $\mathrm{CHB}$, os arquitetos precisam buscar soluções para a nova arquitetura que amenizem o impacto visual degradante que existe na atualidade, pois são as suas atribuições profissionais que o tornam capazes de fazer a transformação ser aliada do passado e não mais uma adversária. Para alcançar um resultado positivo não basta para o arquiteto o conhecimento projetual, ele precisa se despir de gosto pessoal e modismos. É necessário ir além do seu tempo, ter consciência que existe uma continuidade, e que esta necessita ser harmônica.

\section{Considerações finais}

Os três casos aqui abordados envolvem questões relacionadas à prática projetual do arquiteto contemporâneo diante da difícil tarefa de atuar em áreas preexistentes, destacando o olhar profissional em relação ao patrimônio construído.

A categorização dos níveis de intervenção abordada por Gracia (1991) deu embasamento a seleção dos objetos de análise. Ao analisar três intervenções com diferentes graus de complexidade, realizadas no Centro Histórico de Belém, se buscou um maior aprofundamento no tema, por meio da avaliação do problema projetual a ser resolvido, da observação das posturas adotadas em cada caso, dos elementos norteadores das propostas, do nível de comprometimento do profissional com o conjunto edificado, e das dificuldades encontradas nas intervenções.

A escassez do tema nas universidades brasileiras é um dos fatores que talvez mais contribua com uma enorme resistência do profissional em relação à temática do patrimônio construído, pois muitas vezes o egresso é surpreendido ao se deparar com a responsabilidade de projetar numa preexistência, sem o conhecimento necessário para tal, e coloca em risco a permanência de importantes testemunhos e relações que envolvem aquele patrimônio cultural, os quais extrapolam os limites da edificação, pela relação de pertencimento que ela atribui ao lugar.

A ausência de referenciais teóricos consistentes e de conhecimento tecnológico, aliada a falta de sensibilidade com relação ao patrimônio cultural de nossas cidades, contribui com um cenário urbano repleto de resultados negativos. Esses resultados têm reflexo direto na salvaguarda da essência da coletividade, dada a importância dos espaços na construção da memória e, consequentemente da identidade de um local.

$\mathrm{Na}$ sua maioria os resultados positivos podem ser associados a alguns fatores, aqui encarados como diretrizes para a realização de um projeto em edificações preexistentes, dentre os quais podemos destacar:

1. A necessidade de maior aprofundamento na pesquisa documental acerca do objeto de intervenção;

2. A realização de uma leitura mais ampla do conjunto onde a edificação está inserida, no intuito de captar os elementos que assumem papel de destaque no sistema tipológico do entorno e tirar partido dessa correspondência;

3. Aproximação com os reais usuários do espaço, no intuito assimilar o significado do objeto frente à coletividade;

4. Base teórico-conceitual consistente que possibilite uma maior segurança na tomada de decisões, baseadas na relação entre permanências $\mathrm{e}$ transformações do ambiente construído, que envolvem o vínculo deste com as pessoas. Não elimina as teorias do restauro. A teoria e a prática estão no mesmo patamar de importância que as aspirações das pessoas de uma sociedade proprietária do bem. Essa teoria é assim complementada por várias outras áreas da humanidade, mas como a discussão pertence às ciências do patrimônio, humanidades, ciência e tecnologia caminham juntas. É, portanto, uma relação já apresentada por Riegl (2013) quando conceitua o que é monumento e o relaciona com a memória, da mesma maneira que Brandi (2008) e enfatiza a teoria e prática como campos complementares.

5. Afirmação enquanto arquitetura contemporânea, que deve se inserir de forma harmoniosa no ambiente construído, sem agredir ou mesmo descaracterizar o espaço histórico. 
Ressalta-se, por fim, a urgência com a qual a academia precisa encarar essa temática, fundamental à formação dos arquitetos e urbanistas, tendo em vista a necessidade de se projetar cada vez mais em contextos preexistentes.
E que, a partir de então, pautado na tríplice: conhecimento, sensibilidade e senso crítico, o arquiteto consiga atuar de forma consciente ao se deparar com o desafio de construir no construído.

\section{Agradecimentos}

À Coordenação de Aperfeiçoamento Pessoal de Nível Superior (CAPES) pelo suporte financeiro da bolsa de pesquisa ao primeiro autor; ao Conselho Nacional de Desenvolvimento Científico e Tecnológico $(\mathrm{CNPq})$ pelo projeto Procad/Casadinho, processo $\mathrm{n}^{\circ}$ 552690/2001-2; à $2^{\mathrm{a}}$ SR/IPHAN por possibilitar o acesso aos processos e mapas utilizados no trabalho; à FUMBEL pelos mapas fornecidos; ao arquiteto Flávio Nassar, por disponibilizar o vasto acervo fotográfico; à arquiteta Roseane Norat pelo acesso às informações do projeto do Sesc Boulevard; às arquitetas Thais Toscano e Rosário Lima pelo acesso às informações referentes ao projeto Bechara Mattar.

\section{Notas}

(1) Ao observar os diferentes graus de intervenção, a partir das modificações arquitetônicas, Francisco de Gracia (1991), propõe a criação de uma teoria para intervir no patrimônio edificado das cidades, oferecendo ferramentas para projetar nos centros urbanos. Categoriza os níveis de intervenção, dividindo-os em três grupos: modificação circunscrita; modificação do lócus; e pauta de conformação urbana.

(2) O nível apresentado por Gracia (1991) como pauta de conformação urbana inclui intervenções com alcance urbano, que afetam de forma direta a morfologia urbana de uma área.

(3) $\mathrm{Na}$ modificação circunscrita a intervenção se restringe ao edifício individualmente, incluindo desde intervenções de restauração à ampliação moderada e transformação da estrutura interna.

(4) A categoria citada por Gracia (1991) como modificação do lócus corresponde a intervenções arquitetônicas que, apesar de restritas a edificações de forma pontual, terminam por repercutir sobre os contextos urbanos construídos.

(5) Conferência Internacional sobre Conservação “Cracóvia 2000”. Cracóvia, Polônia, 2000.

(6) Informações obtidas a partir de contato pessoal com a arquiteta Maria Dorotéa de Lima, membro da comissão julgadora do concurso nacional para o Projeto do Ver-o-Peso, em 1998, e atual superintendente da $2^{\text {a }}$ SR/IPHAN.

(7) Flávio Ferreira. Projeto original, p. 02.

(8) Informações obtidas a partir de contato pessoal com a arquiteta Roseane Norat, uma das autoras do projeto de intervenção do edifício sede do Sesc Boulevard, em Belém/PA.

(9) Paulo Chaves Fernandes Arquitetura. Memorial Descritivo do Projeto Bechara Mattar e Hotel Belém, março 2010.

(10) Informações obtidas a partir de entrevista com os autores do projeto Bechara Mattar, Paulo Chaves Fernandes; Rosário Lima da Silva; Thais Zumero Toscano. Belém, setembro de 2014.

(11) IPHAN. No tocante ao parecer referente ao projeto Bechara Matar, constante no ofício no 025/2010 - 2 ${ }^{\mathrm{a}}$ SR/IPHAN/PA.

\section{Referências}

ARENDT, Hanna. Entre o passado e o futuro. Trad. Mauro Almeira. São Paulo, Perspectiva, 2000.

ARGAN, Giulio Carlo. História da Arte como História da Cidade. São Paulo: Martins Fontes, 1998.

ARQUITETURAS - Mercado Ver-o-Peso. Paulo Markun (direção); Sergio Roizenblit (direção); Ana Roxo (roteiro); Larissa Nogueira (produção); Denise Resende (produção); Carime Franco (produção). Revanche Produções. Miração Filmes. Realização Sesc Tv, 2013. Duração: 51'13'’. Disponível em: https://www.youtube.com/watch?v=y4UPeyMyKpw. Acesso em 22 fev. 2015.

BELÉM (Município). Lei 7.709 de 18 de maio de 1994. Dispõe sobre a preservação do patrimônio histórico, artístico, cultural e paisagístico do município de Belém. Diário Oficial do Município de Belém. Belém, 1994. Disponível em:

http://www.belem.pa.gov.br/planodiretor/legislacao/municipal. Acesso em 27/02/2014.

BRANDI, Cesare. Teoria da restauração. Tradução: Beatriz Mugayar Kühl. 3. ed. Cotia: Ateliê Editorial, 2008.

DOURADO, Odete. Para sempre, memória. Revista RUA, v. 2, n. 2, 1989, p. 65-74.

DOURADO, Odete. Por um Restauro Urbano: Novas Edificações que Restauram Cidades Monumentais. Revista RUA, v. 6, n. 1, $\mathrm{n}^{\mathrm{o}} 8,2003$, p. 08-13. 
GIOVANNONI, Gustavo. Questioni di Architettura nella storia e nella vita: Edilizia, estética architettonica, restauri, ambienti dei monumenti. Roma: Società Editrice d'Arte Illustrata, 1929. 227p.

GRACIA, Francisco de. Construir en lo Construído. Guipuzcoa, Espanha: NEREA, 1991.

GRAMMONT, Anna Maria de. Hotel Pilão: um incêndio no coração de Ouro Preto. São Paulo, SP: Giordanus, 2006. 249p.

MORENO-NAVARRO, Antoní González. La Restauración objetiva (método SCCM de restauración monumental): memoria SPAL 1993-1998. Barcelona: Diputación de Barcelona. Área de Cooperación. Servicio de Patrimonio Arquitectónico Local, 1999. v. 3 .

MUÑOZ-VIÑAS, Salvador. Teoria Contemporanea de la Restauración. Madrid: Editorial Síntesis, 2004.

RIEGL, Alois. O culto moderno dos monumentos e outros ensaios estéticos. Coimbra, Portugal: Edições 70, 2013.

ROSSI, Aldo. A Arquitetura da Cidade. São Paulo: Martins Fontes, 1995.

\section{${ }^{1}$ Márcia Teixeira Filgueira Forte}

Arquiteta e urbanista. Mestre em Arquitetura e Urbanismo pela Universidade Federal do Pará (UFPA). Endereço postal: Rua Augusto Corrêa, 01, Cidade Universitária, Campus Profissional, Atelier de Arquitetura e Urbanismo, LACORE, Guamá, Belém, PA, Brasil. CEP 66075-110.

\section{Thais Alessandra Bastos Caminha Sanjad}

Arquiteta e urbanista. Doutora em Ciências pela Universidade Federal do Pará (UFPA) e professora do Programa de Pós-graduação em Arquitetura e Urbanismo da Universidade Federal do Pará (PPGAU/UFPA). Endereço postal: Rua Augusto Corrêa, 01, Cidade Universitária, Campus Profissional, Atelier de Arquitetura e Urbanismo, LACORE, Guamá, Belém, PA, Brasil. CEP 66075-110. 